\title{
Kalirin Binds the NR2B Subunit of the NMDA Receptor, Altering Its Synaptic Localization and Function
}

\author{
Drew D. Kiraly, Fouad Lemtiri-Chlieh, Eric S. Levine, Richard E. Mains, and Betty A. Eipper \\ Department of Neuroscience, University of Connecticut Health Center, Farmington, Connecticut 06030
}

The ability of dendritic spines to change size and shape rapidly is critical in modulating synaptic strength; these morphological changes are dependent upon rearrangements of the actin cytoskeleton. Kalirin-7 (Kal7), a Rho guanine nucleotide exchange factor localized to the postsynaptic density (PSD), modulates dendritic spine morphology in vitro and in vivo. Kal7 activates Rac and interacts with several PSD proteins, including PSD-95, DISC-1, AF-6, and Arf6. Mice genetically lacking Kal7 (Kal7 ${ }^{\mathrm{KO}}$ ) exhibit deficient hippocampal long-term potentiation (LTP) as well as behavioral abnormalities in models of addiction and learning. Purified PSDs from Kal ${ }^{\mathrm{KO}}$ mice contain diminished levels of NR2B, an NMDA receptor subunit that plays a critical role in LTP induction. Here we demonstrate that Kal $7^{\mathrm{KO}}$ animals have decreased levels of NR2B-dependent NMDA receptor currents in cortical pyramidal neurons as well as a specific deficit in cell surface expression of NR2B. Additionally, we demonstrate that the genotypic differences in conditioned place preference and passive avoidance learning seen in $\mathrm{Kal} 7{ }^{\mathrm{KO}}$ mice are abrogated when animals are treated with an NR2B-specific antagonist during conditioning. Finally, we identify a stable interaction between the pleckstrin homology domain of Kal7 and the juxtamembrane region of NR2B preceding its cytosolic C-terminal domain. Binding of NR2B to a protein that modulates the actin cytoskeleton is important, as NMDA receptors require actin integrity for synaptic localization and function. These studies demonstrate a novel and functionally important interaction between the NR2B subunit of the NMDA receptor and Kalirin, proteins known to be essential for normal synaptic plasticity.

\section{Introduction}

Kalirin-7 (Kal7), one of approximately a dozen Rho guanine nucleotide exchange factors (GEFs) localized to the postsynaptic density (PSD) (Kiraly et al., 2010a), is one of many molecules important for dendritic spine formation and function (Carlisle and Kennedy, 2005; Bourne and Harris, 2007; Hung et al., 2008). Kal7 is critical for spine formation in cultured hippocampal and cortical neurons (Ma et al., 2003, 2008a) and in vivo (Ma et al., 2008b). Kal7 knock-out (Kal7 ${ }^{\mathrm{KO}}$ ) mice exhibit decreased hippocampal spine density at baseline (Ma et al., 2008b), with aberrant spine plasticity in the nucleus accumbens after repeated cocaine injections (Kiraly et al., 2010b). In addition to morphological alterations, $\mathrm{Kal}^{\mathrm{KO}}$ mice have decreased passive avoidance fear conditioning and decreased conditioned place preference for cocaine (Ma et al., 2008b; Kiraly et al., 2010b). However, Kal7 ${ }^{\mathrm{KO}}$ mice are normal in object recognition, radial arm maze acquisition, and acute locomotor response to cocaine. Decreased levels

\footnotetext{
Received June 21, 2011; revised July 10, 2011; accepted July 14, 2011

Author contributions: D.D.K., R.E.M., and B.A.E. designed research; D.D.K., F.L.-C., R.E.M., and B.A.E. performed research; D.D.K., E.S.L., R.E.M., and B.A.E. analyzed data; D.D.K., E.S.L., R.E.M., and B.A.E. wrote the paper.

The authors declare no competing financial interests.

These studies were supported by National Institutes of Health Grants DA-15464, DA-18274, DA-23082, and DA-26706. We thank Darlene D'Amato Yanping Wang, and Chris Mazzone for amazing technical support. We also thank Jodi Eipper-Mains for the original version of the drawing used in Figure 7, and Dr. Marina Wolf for advice on cross-linking.

Correspondence should be addressed to Betty Eipper, 263 Farmington Avenue, Department of Neuroscience, Farmington, CT 06030. E-mail: eipper@nso.uchc.edu.

F. Lemtiri-Chlieh's present address: The King Abdullah University of Science and Technology, Thuwal, 23955H6900, Kingdom of Saudi Arabia.

DOI:10.1523/JNEUROSCI.3143-11.2011

Copyright $\odot 2011$ the authors $\quad 0270-6474 / 11 / 3112554-12 \$ 15.00 / 0$
}

of the NR2B subunit of the NMDA receptor were observed in PSDs from Kal7 ${ }^{\mathrm{KO}}$ mice (Ma et al., 2008b). These studies indicate that Kal7 has profound, specific effects on normal synaptic function.

NMDA receptors are ionotropic glutamate receptors critical for many forms of synaptic plasticity, including long-term potentiation (LTP) and long-term depression (LTD), considered cellular correlates of learning and memory (Cull-Candy and Leszkiewicz, 2004; Kerchner and Nicoll, 2008). NMDA receptors are tetramers primarily composed of obligate NR1 subunits, binding coagonist glycine, and NR2 subunits (mainly A and B in adult forebrain), which bind glutamate (Cull-Candy and Leszkiewicz, 2004). NR2A-containing receptors support higher peak currents and faster deactivation kinetics, while NR2B-containing receptors exhibit prolonged channel open times and greater overall $\mathrm{Ca}^{2+}$ current per event (Sobczyk et al., 2005; Yashiro and Philpot, 2008). Within the PSD, NMDA receptors are embedded in a macromolecular complex (Husi and Grant, 2001). The juxtamembrane intracellular domains of the NMDA receptor subunits bind proteins that affect channel function and the cytoskeleton. Calmodulin binding to the juxtamembrane region of NR1 leads to its inactivation (Ehlers et al., 1996). Spectrin and $\alpha$-actinin bind to the C-terminal domains of NR1 and NR2B (Wyszynski et al., 1997; Wechsler and Teichberg, 1998). Different endocytic motifs in the juxtamembrane regions of NR1 and NR2B target receptors for recycling and degradation (Scott et al., 2004). The coordinated interactions of NMDA receptors with these binding partners are essential for proper synaptic function.

A growing body of evidence suggests that NR2B plays a critical role in many forms of learning and plasticity. Genetic elimination 
of NR2B in hippocampal neurons abolishes NMDA receptordependent LTP, reduces dendritic spine density, and decreases the ratio of filamentous to globular actin (Akashi et al., 2009). NR2B localized with CaMKII in perisynaptic regions is critical for LTP development in hippocampal slices (Barria and Malinow, 2005; Foster et al., 2010). In agreement with electrophysiological experiments, the contribution of NR2B subunits to channel function is important for conditioned place preference for cocaine and morphine and for normal fear conditioning (Rodrigues et al., 2001; Ma et al., 2006; Pascoli et al., 2011). Here, we demonstrate that Kal7 interacts with the juxtamembrane region of NR2B and that $\mathrm{Kal}{ }^{\mathrm{KO}}$ mice have decreased NR2B subunit-containing NMDA receptor currents and cell surface expression. Furthermore, behavioral differences between wild-type (Wt) and Kal7 ${ }^{\mathrm{KO}}$ mice in cocaine place preference and passive avoidance are abrogated by blockade of NR2B subunit-containing receptors.

\section{Materials and Methods}

\section{Electrophysiology}

For electrophysiological recordings, Wt and $\mathrm{Kal}^{\mathrm{KO}}$ animals [postnatal days (P) 28-40] were decapitated under isoflurane anesthesia and the brains were placed into ice-cold "cutting and incubating" (CI) solution composed of (in mM): $125 \mathrm{NaCl}, 2.5 \mathrm{KCl}, 1.25 \mathrm{NaH}_{2} \mathrm{PO}_{4}, 25 \mathrm{NaHCO}_{3}$, $0.5 \mathrm{CaCl}_{2}, 4 \mathrm{MgCl}_{2}, 4 \mathrm{MgSO}_{4}$, 4 lactic acid, 2 pyruvic acid, 20 glucose, and 0.4 ascorbic acid, carboxygenated with $95 \% \mathrm{O}_{2} / 5 \% \mathrm{CO}_{2}$ ( $\mathrm{pH} 7.3,310 \pm$ $\left.5 \mathrm{mmol} \cdot \mathrm{kg}^{-1}\right)$. Transverse cortical slices $(350 \mu \mathrm{m})$ were cut using a vibratome and placed into an incubating chamber containing CI solution at $35^{\circ} \mathrm{C}$ for $30 \mathrm{~min}$ before being transferred to room temperature for at least $30 \mathrm{~min}$ before recording. During recordings, slices were continuously perfused at $2 \mathrm{ml} / \mathrm{min}$ with artificial cerebrospinal fluid (ACSF) consisting of the following (in mM): $125 \mathrm{NaCl}, 2.5 \mathrm{KCl}, 1.25 \mathrm{NaH}_{2} \mathrm{PO}_{4}, 25$ $\mathrm{NaHCO}_{3}, 2 \mathrm{CaCl}_{2}, 2 \mathrm{MgCl}_{2}$, and 15 glucose $\left(\mathrm{pH} 7.3,310 \pm 5 \mathrm{mmol} \cdot \mathrm{kg}^{-1}\right) ; \mathrm{pH}$ was equilibrated by continuous bubbling with $95 \% \mathrm{O}_{2} / 5 \% \mathrm{CO}_{2}$.

Whole-cell voltage-clamp recordings $\left(V_{\text {hold }}=-70 \mathrm{mV}\right)$ were obtained from layer $2 / 3$ cortical pyramidal neurons. The pipette solution contained the following (in mM): $117 \mathrm{CH}_{3} \mathrm{O}_{3} \mathrm{SCs}, 8 \mathrm{CsCl}, 10 \mathrm{HEPES}, 2$ EGTA, $0.2 \mathrm{CaCl}_{2}, 4 \mathrm{Mg}^{2+}$-ATP, $0.3 \mathrm{Na}^{+}$-GTP, and 5 QX-314 (pH 7.3, $\left.295 \pm 5 \mathrm{mmol} \cdot \mathrm{kg}^{-1}\right)$. Upon breaking into whole-cell configuration, a brief series of voltage ramps ( $50 \mathrm{~ms}, 2 \mathrm{mV} / \mathrm{ms}$ ) were applied to promote the activity-dependent block of the sodium conductance by QX-314. Electrical events were filtered at $2.9 \mathrm{kHz}$ and digitized at $\geq 6 \mathrm{kHz}$. Series resistance was compensated $70 \%$ at $10-100 \mu$ s lag. Input resistance $\left(R_{\mathrm{i}}\right)$ was monitored with $5 \mathrm{mV} / 50 \mathrm{~ms}$ hyperpolarizing voltage steps. Electrically evoked EPSCs were elicited with a bipolar tungsten electrode (resistance, $1 \mathrm{M} \Omega$ ) positioned $60-120 \mu \mathrm{m}$ lateral to the patched neuron in layer $2 / 3$. Voltage measurements were not corrected for the calculated liquid junction potential of $-10.2 \mathrm{mV}$. Stimulation consisted of a single square-wave current pulse (duration, 50-150 $\mu$ s; amplitude, 50-200 $\mu \mathrm{A}$ at a frequency of $0.067 \mathrm{~Hz}$ ) designed to evoke half-maximal responses. Neurons were discarded from analyses whether: (1) $R_{\mathrm{s}}$ was $>25 \mathrm{M} \Omega$ at the time of break in or $>10.5 \mathrm{M} \Omega$ after compensation; (2) if $R_{\mathrm{i}}$ changed by $>15 \%$ during the course of an experiment; or (3) if $R_{\mathrm{i}}$ fell below 100 $M \Omega$. For determination of NMDA/AMPA receptor current ratios, the AMPA receptor current was quantified as the peak current recorded at $V_{\mathrm{h}}=-70 \mathrm{mV}$, and the NMDA receptor current was quantified $40 \mathrm{~ms}$ after stimulation onset at $V_{\mathrm{h}}=+40 \mathrm{mV}$. For antagonist studies, NR2B subunit antagonists (ifenprodil and Ro 25-6981; Tocris Bioscience) were dissolved in water.

\section{$B S^{3}$ cross-linking}

Methods for labeling cortical slices with membrane-impermeable BS $^{3}$ cross-linker were adapted from published procedures (Boudreau and Wolf, 2005; Sears et al., 2010). Age matched Wt and Kal7 ${ }^{\mathrm{KO}}$ mice were decapitated and their brains were removed into slush-cold slicing ACSF (S-ACSF) composed of the following (in $\mathrm{mM}$ ): 26 HEPES, pH 7.4, 250 sucrose, $2.3 \mathrm{KCl}, 2 \mathrm{CaCl}_{2}, 2 \mathrm{MgSO}_{4}, 1.26 \mathrm{KH}_{2} \mathrm{PO}_{4}, 10$ glucose. Coronal cortical vibratome slices $(400 \mu \mathrm{M})$ were transferred from slush-cold
S-ACSF to tubes containing ice-cold cross-linking ACSF (X-ACSF) composed of the following (in mM): $26 \mathrm{HEPES}, \mathrm{pH} 7.4,125 \mathrm{NaCl}, 2.3 \mathrm{KCl}, 2$ $\mathrm{CaCl}_{2}, 2 \mathrm{MgSO}_{4}, 1.26 \mathrm{KH}_{2} \mathrm{PO}_{4}, 10$ glucose. To prevent any receptor trafficking, slices were kept ice cold for all steps until tissue lysis. Slices were washed twice with X-ACSF before the addition of X-ACSF containing $2 \mathrm{~mm} \mathrm{BS}^{3}$ [bis(sulfosuccinimidyl) suberate; Pierce]. Slices were incubated with $\mathrm{BS}^{3}$ for 40 min with agitation to allow for full labeling of cell surface receptors. Unreacted $\mathrm{BS}^{3}$ was quenched by adding glycine to 10 mM. This solution was aspirated and replaced with X-ACSF plus $5 \mathrm{~mm}$ glycine. The second wash solution was aspirated and slices were sonicated into $250 \mu \mathrm{l}$ of SDS lysis buffer ( $50 \mathrm{~mm}$ Tris, $\mathrm{pH}=8.0,2 \%$ SDS, $5 \mathrm{~mm}$ EDTA, $50 \mathrm{~mm} \mathrm{NaF}, 1 \mathrm{~mm}$ dithiothreitol, $1 \mathrm{~mm}$ PMSF, and protease inhibitor cocktail) (Xin et al., 2004). After incubation at $55^{\circ} \mathrm{C}$ for $10 \mathrm{~min}$, lysates were spun for $20 \mathrm{~min}$ at $25,000 \times \mathrm{g}$ at room temperature. Protein concentrations were determined by bicinchoninic acid assay (Pierce), and $20 \mu \mathrm{g}$ of protein was mixed with $1 \times$ Laemmli buffer and heated to $55^{\circ} \mathrm{C}$ for $5 \mathrm{~min}$. Proteins separated on a $4-15 \%$ acrylamide gel were transferred to PVDF membranes, and Western blotting was performed as described previously (Ma et al., 2008b). Quantification of discrete intracellular and diffuse surface bands was performed using GeneGnome software (Ma et al., 2008b). Surface receptor included a signal associated with a higher molecular weight than that of the non-cross-linked receptor; background signal was subtracted out.

\section{Behavioral experiments}

Animals were group housed in the University of Connecticut Health Center (UCHC; Farmington, CT) animal facility on a $12 \mathrm{~h}$ light-dark cycle (lights on 7:00A.M., off 7:00 P.M.). All experiments were performed in accordance with UCHC Institutional Animal Care and Use Committee and National Institutes of Health procedures for animal care. Male Wt and Kal7 ${ }^{\mathrm{KO}}$ (Ma et al., 2008b) littermate mice 2-6 months of age were used throughout. These mice have been backcrossed into the C57BL/ 6 background for $\geq 15$ generations. Behavioral studies using ifenprodil to distinguish the role of NR2B-containing NMDA receptors have used doses ranging from 1 to $10 \mathrm{mg} / \mathrm{kg}$ administered intraperitoneally (Rodrigues et al., 2001; Liu et al., 2006; Ma et al., 2006; Schumann and Yaka, 2009). To minimize any effect on NR2A-containing NMDA receptors (Williams, 1993), we chose a low dose $(2 \mathrm{mg} / \mathrm{kg}$ ) that was reported to reduce conditioned place preference and passive avoidance (Rodrigues et al., 2001; Liu et al., 2006; Ma et al., 2011).

Conditioned place preference. Conditioned place preference methods were adapted from our previously published experiments (Kiraly et al., $2010 \mathrm{~b}$ ). To determine the role of NR2B-containing receptors in these behaviors, ifenprodil ( $2 \mathrm{mg} / \mathrm{kg}$ in saline) was injected (i.p.) $10 \mathrm{~min}$ before the injection of saline or cocaine (National Institute on Drug Abuse, Bethesda, MD). The timing of these injections was chosen based on a morphine place preference study in rats (Ma et al., 2006). On the first day of the experiment, each animal was given a 20 min pretest session in which they were allowed to explore all chambers of the place preference apparatus freely. The least preferred side became the side paired with drug injections. Animals that showed a $<30 \mathrm{~s}$ difference in baseline preference were assigned to balance chamber side with treatment and genotype. During training there were two conditioning sessions each day: in the morning all animals received saline injections; in the afternoon animals received either ifenprodil $(2 \mathrm{mg} / \mathrm{kg}$ ) or saline $10 \mathrm{~min}$ before cocaine $(10 \mathrm{mg} / \mathrm{kg})$ or saline. Five minutes after the cocaine or saline injection, animals were placed into the conditioning chamber for $15 \mathrm{~min}$. This conditioning was repeated for $4 \mathrm{~d}$. Twenty-four hours after the final conditioning session, animals were again placed into the boxes and allowed to explore all chambers freely. Preference score was calculated as the time spent in the conditioned chamber on the final day minus the amount spent in the same chamber on the pretest day.

Locomotor monitoring. Measurement of the effects of ifenprodil on locomotor activity with and without cocaine was performed using a Latin square design (Benavides et al., 2007; Kiraly et al., 2010b). After a single day of habituation to the locomotor chambers, animals were given i.p. injections of saline, ifenprodil $(2 \mathrm{mg} / \mathrm{kg})$, cocaine $(10 \mathrm{mg} / \mathrm{kg})$, or concomitant ifenprodil plus cocaine in a randomized order over $4 \mathrm{~d}$. Immediately after injection, animals were placed into the locomotor 
monitoring chambers (San Diego Instruments) and their activity was recorded for $45 \mathrm{~min}$.

Passive avoidance. Methods were adapted from our previous procedure (Ma et al., 2008b). A single injection of ifenprodil ( $2 \mathrm{mg} / \mathrm{kg}$, i.p.) or saline was administered 15 min before passive avoidance conditioning. For conditioning, animals were placed into one side of a shuttle box; after $5 \mathrm{~s}$ the house light came on in that chamber only and the door between chambers was opened. When the animal crossed to the dark compartment, the door was closed and the animal received a single $0.3 \mathrm{~mA} \times 2 \mathrm{~s}$ scrambled footshock. Previous studies with these mice showed that this stimulus was sufficient to elicit robust conditioning and that there were no genotypic differences in shock sensitivity (Ma et al., 2008b). After the context-shock pairing, animals were returned to their home cages. Twenty-four hours after training, animals were returned to the same boxes and their latency to cross was measured. Increases in latency to cross were used as an index of the strength of conditioning.

\section{Synaptosomes}

For coimmunoprecipitation experiments, synaptosomes were prepared from adult rat or mouse brain (pooled cortex, striatum, and hippocampus). Briefly, brains were homogenized in 20 volumes of Buffer A ( $20 \mathrm{~mm}$ Tris- $\mathrm{HCl}, \mathrm{pH}$ 7.4, $320 \mathrm{~mm}$ sucrose, $5 \mathrm{~mm}$ EDTA, $50 \mathrm{~mm} \mathrm{NaF}, 2 \mathrm{~mm}$ sodium orthovanadate, $1 \mathrm{~mm}$ PMSF, and protease inhibitor cocktail) (Xin et al., 2004) and centrifuged at $1000 \times g$ for $10 \mathrm{~min}$. The supernatant was then centrifuged at $15,000 \times g$ for $15 \mathrm{~min}$, yielding a crude synaptosomal fraction (P2) that was resuspended in TE buffer (10 mM Tris- $\mathrm{HCl}$, pH7.4, 5 mм EDTA, PMSF, protease inhibitor cocktail). Three solubilization protocols were used. In the first protocol, a mixture of Triton X-100 (TX-100; $1.0 \%)$ and SDS $(0.1 \%)$ was used; samples were tumbled for $1 \mathrm{~h}$ at $4^{\circ} \mathrm{C}$ and then centrifuged for $40 \mathrm{~min}$ at $20,000 \times g$. The TX100/SDS supernatant was used for analysis. For protocol 2, 10\% deoxycholate (DOC) in $500 \mathrm{~mm}$ Tris, $\mathrm{pH} 9.0$, was added to a concentration of $1 \%$ DOC, and samples were tumbled for $1 \mathrm{~h}$ at $4^{\circ} \mathrm{C}$. Triton X-100 $(0.1$ volume of $1.0 \%$ TX-100 in $500 \mathrm{~mm}$ Tris $\cdot \mathrm{HCl}, \mathrm{pH} 9.0$, was added to DOC lysates, which were dialyzed overnight against binding buffer $(50 \mathrm{~mm}$ Tris - HCl, pH 7.4, 0.1\% TX-100) (Dunah et al., 2000; Wyszynski et al., 2002). Dialyzed DOC lysates were centrifuged for $40 \mathrm{~min}$ at $40,000 \times g$ and supernatants were used for immunoprecipitation. For protocol 3 , $10 \%$ SDS was added to a final concentration of $1 \%$ and samples were tumbled for $30 \mathrm{~min}$ at room temperature; samples were then centrifuged and the supernatant was used for immunoprecipitation. Protocol 2 (DOC) was used for all coimmunoprecipitation experiments with the exception of a single method comparison experiment.

\section{Immunoprecipitation}

Samples were precleared by incubation with $15 \mu \mathrm{l}$ of protein A/G beads (Thermo Scientific) for 30-45 min. An aliquot of each sample was saved as input; antibody $(3-4 \mu \mathrm{g})$ and protein $\mathrm{A} / \mathrm{G}$ beads $(15 \mu \mathrm{l})$ were added to each sample, which was tumbled at $4^{\circ} \mathrm{C}$ for $4 \mathrm{~h}$ or overnight. For Kal7 immunoprecipitation, Kal7 monoclonal antibody 20D8 (Ma et al., 2008 b) was enriched by ammonium sulfate precipitation (45\% saturation) of ascites fluid and dialyzed into $10 \mathrm{~mm}$ sodium phosphate, $\mathrm{pH} 7.4$, $150 \mathrm{~mm} \mathrm{NaCl}$. The ammonium sulfate precipitate $(0.4 \mathrm{mg}$ protein $)$ was linked to $0.2 \mathrm{ml}$ of AminoLink Plus Coupling Resin using sodium cyanoborohydride (Thermo Scientific). After incubation with antibody plus protein A/G beads or Kal7 monoclonal antibody beads, unbound proteins were removed and beads were washed twice with TMT buffer $(0.5$ $\mathrm{ml}$ of $20 \mathrm{~mm}$ Na-TES, $10 \mathrm{~mm}$ mannitol, pH 7.4, 1.0\% Triton X-100) and then twice with TM buffer $(0.5 \mathrm{ml}$ of $20 \mathrm{~mm} \mathrm{Na-TES,} 10 \mathrm{~mm}$ mannitol, $\mathrm{pH}$ 7.4). Bound proteins were eluted by boiling into $1 \times$ Laemmli sample buffer. For each sample, incubation of equal amounts of protein with preimmune $\operatorname{IgG}$ was used as a negative control for nonspecific binding. IgG was covalently linked to AminoLink Plus Coupling Resin in the same manner as the Kal7 monoclonal antibody.

\section{Antibodies}

Kalirin antibodies were described previously (Ma et al., 2008b) and include rabbit polyclonal antibodies specific to the terminal 20 aa of Kal7 (JH2959) or to spectrin repeat regions 4-7 of Kalirin (JH2582) and mouse monoclonal Kal7 antibody 20D8. The myc monoclonal antibody (9E10) was described previously (Borjigin and Nathans, 1994; Caldwell et al., 1999). Commercially available antibodies used included NR2B (clone 59/20; NeuroMab), NR2A (clone A12W, catalog no. 04-901; Millipore), NR1 (catalog no. 556308; BD Biosciences), PSD-95 (clone K28/ 43; NeuroMab), GluR1 (catalog no. ab31232; Abcam), GFP (catalog no. ab290; Abcam), myc (catalog no. ab9106; Abcam), HA (catalog no. ab9110; Abcam), and pan-MAGUK (clone K28/86; Neuromab).

\section{Transfection of non-neuronal cells}

pEAK Rapid cells (Edge Biosystems) were maintained in DMEM:F12 medium containing $200 \mathrm{U} / \mathrm{ml}$ penicillin G, $20 \mu \mathrm{g} / \mathrm{ml}$ streptomycin sulfate, 25 mM HEPES, and 10\% fetal bovine serum. Cells were fed with serum-free medium for $2 \mathrm{~h}$ before transfection. Vectors encoding rat NMDA receptor subunits and Kal7 were transfected in a mass ratio of 1 NR1:3 NR2:1.5 Kal7. Expression vectors encoding rat NR1, NR2A, and NR2B were generous gifts from Dr. Jon Johnson at the University of Pittsburgh, Pittsburgh, PA (Qian et al., 2005; Clarke and Johnson, 2008), and the expression vector encoding $\triangle \mathrm{NR} 2 \mathrm{~B}$ was a generous gift from $\mathrm{Dr}$. Kelly Foster at Commonwealth Medical College, Scranton, PA (Foster et al., 2010). Modifications of the $\Delta$ NR2B vector were made to create the NR2B juxtamembrane mutants. For the " $2 \mathrm{~B} \rightarrow 2 \mathrm{~A}$ " construct, the terminal 17 residues of $\triangle \mathrm{NR} 2 \mathrm{~B}$ were swapped for the corresponding residues from NR2A; for the "Stub" truncation construct, the NR2A stop transfer sequence (KLR) followed by an AG spacer was inserted; for the "GAGA" construct, the NR2A stop transfer sequence followed by a string of 14 alanines and glycines was inserted. Constructs were verified by DNA sequencing. The Kal7 expression vectors used were described previously: His-myc-Kal7, His-myc- $\Delta$ Kal7, His-myc-KGEF1 $\rightarrow$ 7end (Xin et al., 2008), His-myc-I-10 (Ratovitski et al., 1999), His-myc-Kal7/ND/AA (Schiller et al., 2008), His-myc-Kal7 $\Delta$ CT (Penzes et al., 2001a). and Hismyc-KalGEF1 (Ferraro et al., 2007). The Tiam1 GEF vector (TiamGEF) included tandem C-terminal HA tags (Ferraro et al., 2007). KalPH1-GFP (where $\mathrm{PH} 1$ is pleckstrin homology domain1) was made by inserting EGFP into the N-terminal portion of the previously described Kalirin PH1 vector (Chakrabarti et al., 2005). Vectors were mixed with Lipofectamine 2000 (Invitrogen) in Opti-MEM (Invitrogen) and added to cells for $6 \mathrm{~h}$ at $37^{\circ} \mathrm{C}$. Cells were then fed with glutamate-free medium [MEM plus $200 \mathrm{U} / \mathrm{ml}$ penicillin G, $20 \mu \mathrm{g} / \mathrm{ml}$ streptomycin sulfate, $25 \mathrm{mM}$ HEPES, and GlutaMax (Invitrogen)] to prevent NMDA receptorinduced excitotoxicity. After 24-48 h, cells were scraped into spent medium, pelleted, and solubilized in DOC as described above. Dialyzed lysates were then subjected to immunoprecipitation as described above.

\section{Peptide pulldown}

Synthetic rNR2B(845-861) preceded by a Gly-Ala spacer (H-GAGAQ ${ }^{845}$ FRHCFMGVCSGKPGMV ${ }^{861} \mathrm{NH}_{2}$ ] (Biomatik) was covalently linked to AffiGel-10 beads (Bio-Rad); this sequence follows transmembrane domain 4 and is referred to as the NR2B juxtamembrane domain (2B-JM). Control AffiGel-10 beads were either blocked with ethanolamine in the absence of peptide or linked to $\beta$-endorphin, a peptide with a positive charge similar to that of 2B-JM. Readily soluble proteins (KalPH1-GFP and GFP) were solubilized in TE buffer with $0.02 \%$ TX-100. For less soluble proteins, samples were solubilized in DOC and dialyzed as described for immunoprecipitation; solutions were diluted to $0.02 \% \mathrm{TX}$ 100 before binding. Lysates were mixed with $15 \mu l$ of peptide-coated or control beads. Binding was performed for $4 \mathrm{~h}$ or overnight at $4^{\circ} \mathrm{C}$. After binding, beads were pelleted and washed four times with binding buffer. Bound proteins were then eluted by boiling into Laemmli sample buffer for $5 \mathrm{~min}$. Similar results were obtained using two separate preparations of KalPH1-GFP.

\section{Statistical analyses}

For behavioral experiments, statistical analysis was performed using SigmaPlot. Two-way ANOVA tests were used to determine main effects of genotype, treatment, and any interactions. For experiments in which there was a significant Genotype $\times$ Treatment Interaction, Holm-Sidak post hoc tests were used to parse out specific effects. For analysis of NR2B subunit-containing NMDA receptor currents, an unpaired two-tailed $t$ 


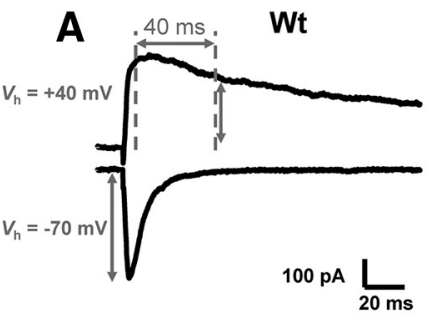

D

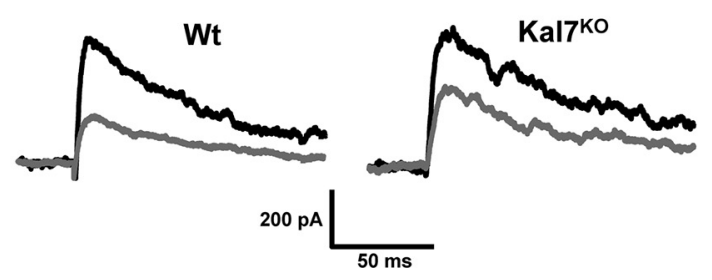

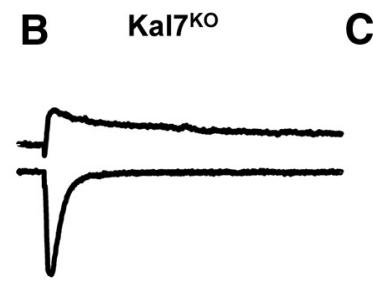

$\mathbf{F}$

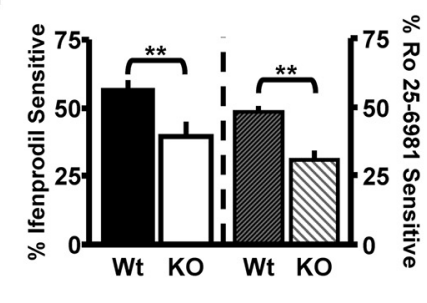

Figure 1. NMDA/AMPA receptor current ratio and NR2B subunit-containing NMDA receptor-mediated currents are diminished in Kal7 ${ }^{\mathrm{K} 0}$ neurons. $\boldsymbol{A}-\boldsymbol{C}$. To measure NMDA/AMPA receptor current ratio in layer 2/3 pyramidal neurons, the AMPA receptor response was quantified as the peak current at a holding potential of $-70 \mathrm{mV}$; the NMDA receptor response was quantified using a holding potential of $+40 \mathrm{mV}$ and was measured $40 \mathrm{~ms}$ after stimulation onset. $\boldsymbol{A}, \boldsymbol{B}$, Representative evoked EPSCs from Wt and $\mathrm{Kal} 7{ }^{\mathrm{K} 0}$ mice at these holding potentials. $\boldsymbol{C}$, Group data for the NMDA/AMPA receptor current ratio in WT and Kal7 ${ }^{\mathrm{K} 0}$ mice $\left({ }^{*} p<\right.$ $0.05 ; t$ test, $n=8$ mice per genotype). $\boldsymbol{D}-\boldsymbol{F}$, To measure NR2B subunit-containing NMDA receptor-mediated currents, layer $2 / 3$ pyramidal neurons were voltage clamped at $+50 \mathrm{mV}$ in the presence of $10 \mu \mathrm{M}$ DNQX to block AMPA receptor-mediated currents. $\boldsymbol{D}, \boldsymbol{E}$, Representative evoked current traces from both genotypes are shown; black traces were made at baseline and gray traces were made 15 min after bath application of an NR2B subunit-specific antagonist, ifenprodil ( $3 \mu \mathrm{M}$ ). $\boldsymbol{F}$, Mean data demonstrate that Wt animals have a significantly larger portion of their NMDA receptor current that is sensitive to ifenprodil (left) or Ro 25-6981 (right; $0.5 \mu \mathrm{m}$ ) a different NR2B subunit-specific antagonist. (ifenprodil, ${ }^{* *} p<0.01 ; t$ test, $n=5$ animals/group, $2-3$ cells/ animal; Ro 25-6981, ${ }^{* *} p<0.01 ; t$ test, $n=3-4$ animals/group, $2-3$ cells/animal).

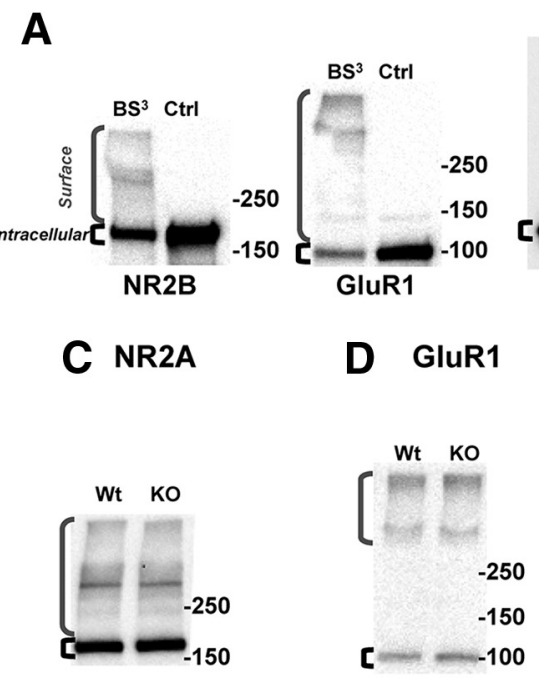

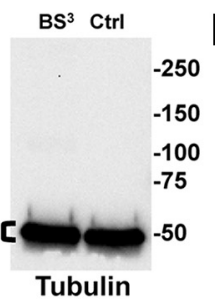

$B_{\text {NR2B }}$

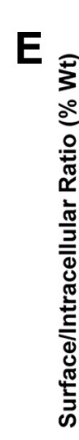

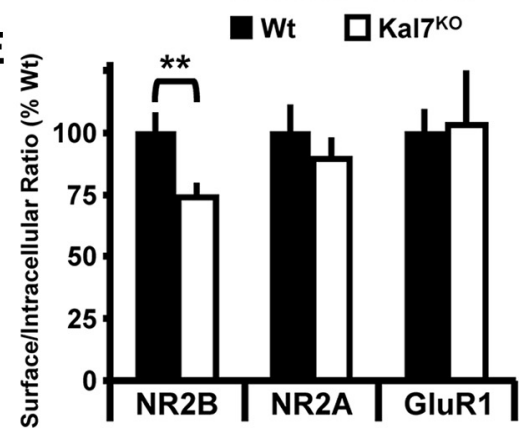

Figure 2. Knock-out of Kal7 specifically decreases surface localization of NR2B subunit. $A$, Exposure of cortical slices kept at $4^{\circ} \mathrm{C}$ to $\mathrm{BS}^{3}$ cross-links surface receptors, producing high molecular weight bands that are not observed in non-cross-linked control (Ctrl) slices; brackets indicate Surface and Intracellular receptors. As expected, an intracellular protein, tubulin, was not crosslinked. $\boldsymbol{B}-\boldsymbol{D}$, Representative Western blots of cross-linked samples from Wt and Kal7 ${ }^{\mathrm{K} 0}$ slices blotted for NR2B (B), NR2A (C), and GluR1 (D). $\boldsymbol{E}$, Surface and Intracellular receptor levels were quantified for each sample, and the Surface/Intracellular ratio for Wt slices was normalized to $100 \%$. Kal7 ${ }^{\mathrm{K} 0}$ animals show a decrease in cell surface expression of NR2B, while surface levels of NMDA receptor subunit NR2A and the AMPA receptor subunit GluR1 were unchanged. ${ }^{* *} p=0.018$ as calculated by $t$ test; $N=9-10$ slices/genotype, 3 animals/group).

test was used to compare the NMDA/AMPA receptor current ratios as well as percentage change of evoked currents after ifenprodil or Ro 256981 application. Unpaired two-tailed $t$ tests were also used to compare surface/intracellular receptor ratios for cross-linking experiments.

\section{Results}

NR2B subunit-containing NMDA receptor currents are reduced in $\mathrm{Kal} 7^{\mathrm{KO}}$ cortical neurons

One of the few changes observed in PSDs isolated from $\mathrm{Kal} 7^{\mathrm{KO}}$ mice was a decrease in NR2B levels (Ma et al., 2008b). To examine changes in ionotropic glutamate receptor signaling in $\mathrm{Kal} 7^{\mathrm{KO}}$ mice, we quantified the ratio of NMDA to AMPA receptor currents in slices of somatosensory cortex from young adult (P28-40) Wt and $\mathrm{Kal}^{\mathrm{KO}}$ mice. The ratio of peak EPSC at $V_{\mathrm{h}}$ of $+40 \mathrm{mV} 40 \mathrm{~ms}$ after stimulation (NMDA receptor-mediated current) over the peak current at $V_{\mathrm{h}}$ of -70 $\mathrm{mV}$ (AMPA receptor-mediated current) was calculated (Fig. $1 A, B$ ). Kal7 ${ }^{\mathrm{KO}}$ mice exhibit a significantly decreased NMDA/ AMPA ratio, indicative of a decrease in overall NMDA receptor function (Fig. 1C). These findings are in line with our previous findings that $\mathrm{Kal} 7{ }^{\mathrm{KO}}$ mice do not form normal NMDA receptor-dependent LTP when looking at single cell (Ma et al., 2008b) or field (F. Lemtiri-Chlieh, D. D. Kiraly, L. Zhao, B. A. Eipper, R. E. Mains, E. S. Levine, unpublished observations) LTP induction protocols.

Given these findings, we used pharmacological tools to compare signaling mediated by the NR2B subunit-containing NMDA receptor in $\mathrm{Wt}$ and $\mathrm{Kal}^{\mathrm{KO}}$ cortical neurons. For these experiments, NMDA receptor-mediated activity was isolated using the AMPA/kainate receptor antagonist 6,7-dinitroquinoxaline-2,3-dione (DNQX; $10 \mu \mathrm{M})$, and cells were voltage clamped at $+50 \mathrm{mV}$ to remove the voltage-dependent blockade of NMDA receptors. Extracellular stimulation within layer $2 / 3$ evoked NMDA receptor-mediated EPSCs in slices from both Wt and $\mathrm{Kal}^{\mathrm{KO}}$ animals (Fig. $1 D, E$, dark traces); these EPSCs were completely blocked by the NMDA receptor antagonist 3-[( \pm$)-2$-carboxypiperazin-4-yl]propyl-1-phosphonic acid (CPP, $3 \mu \mathrm{M}$; data not shown). To determine the NR2B subunit-mediated component of the NMDA receptor current, ifenprodil $(3 \mu \mathrm{M})$ (Tovar and Westbrook, 1999; Madara and Levine, 2008) was added to the bath solution. In slices from Wt animals, the ifenprodil-sensitive component represented $56 \pm 4 \%$ of the peak current, whereas in slices from $\mathrm{Kal} 7{ }^{\mathrm{KO}}$ animals the ifenprodilsensitive component was only $39 \pm 6 \%$ of the peak current (Fig. 1D-F). A different NR2B-specific antagonist, Ro 25-6981 $(0.5 \mu \mathrm{M}$ ) (Liu et al., 2004; Haseneder et al., 2009), produced the same result. In slices from Wt animals, the Ro 25-6981-sensitive component was $48 \pm 2 \%$ of the peak current; in slices from 
Kal7 ${ }^{\mathrm{KO}}$ animals it was only $30 \pm 4 \%$ of the peak current, significantly less than in Wt tissue (Fig. $1 F$, traces not shown). These data indicate that the decrease in NR2B subunit levels observed in cortical PSDs is associated with a decrease in NR2B subunitcontaining NMDA receptor functionality in Kal7 ${ }^{\mathrm{KO}}$ animals.

Surface localization of NR2B is reduced in $\mathrm{Kal} 7^{\mathrm{KO}}$ animals To determine whether the decrease in ifenprodil-sensitive currents in the $\mathrm{Kal}^{\mathrm{KO}}$ animals was due to changes in synaptic localization or receptor function, we used membrane-impermeable $\mathrm{BS}^{3}$ cross-linking to identify surface receptors (Boudreau and Wolf, 2005; Sears et al., 2010). Cortical slices from adult Wt and $\mathrm{Kal} 7{ }^{\mathrm{KO}}$ mice were chilled to $4^{\circ} \mathrm{C}$ before cross-linking to prevent receptor trafficking. High molecular weight bands representing cross-linked NMDA and AMPA receptors were seen only in cross-linked slices (Fig. 2A). Additionally, Western blot analysis of tubulin, an intracellular protein, revealed a single discrete band of the appropriate molecular weight, demonstrating that $\mathrm{BS}^{3}$ was unable to enter cells (Fig. $2 A$, right). We examined the NR2B and NR2A subunits of the NMDA receptor as well as the GluR1 subunit of the AMPA receptor (Fig. 2B-D). Quantification of Surface (high molecular weight) to Intracellular ratios for these receptor subunits revealed a specific decrease in surface expression of the NR2B subunit in Kal7 ${ }^{\mathrm{KO}}$ mice (Fig. 2 E); surface levels of the NR2A subunit and the GluR1 subunit were unaltered. Surface biotinylation experiments of cortical slices kept at $4^{\circ} \mathrm{C}$ to block trafficking revealed the same patterns of surface expression for these three receptor subunits (data not shown).

\section{Differences in $\mathrm{Wt}$ and $\mathrm{Kal} 7^{\mathrm{KO}}$ mouse place preference for cocaine are eliminated by ifenprodil}

Given the specific decreases in NR2B subunit localization and function in $\mathrm{Kal} 7^{\mathrm{KO}}$ mice, we wanted to determine if any of the behavioral differences in $\mathrm{Kal}^{\mathrm{KO}}$ mice might be attributable to a diminished contribution from NR2B-containing NMDA receptors. $\mathrm{Kal} 7^{\mathrm{KO}}$ animals display a substantially reduced conditioned place preference for cocaine despite their normal place preference for food (Kiraly et al., 2010b). Previous studies from other laboratories demonstrated that NR2B function is critical for development of cocaine or morphine place preference (Ma et al., 2006; Pascoli et al., 2011). To test our hypothesis, we repeated the place preference experiment for cocaine but tried to eliminate the contribution of NR2B subunit-containing NMDA receptor signaling by injecting ifenprodil before cocaine on each conditioning day (Fig. 3A). To optimize specificity for NR2B-containing receptors (Williams, 1993), we chose a dose of ifenprodil (2 mg/kg) in the lower end of the range previously reported to have behavioral effects (Rodrigues et al., 2001). A higher dose of ifenprodil or Ro 25-6981 (10 mg/kg for both) was used in previous studies of NR2B in drug preference (Ma et al., 2006; Pascoli et al., 2011).

As expected, animals receiving only saline injections showed no significant changes from baseline; ifenprodil on its own created no preference or aversion (Fig. 3B, left) (Genotype, Treatment and Interaction effects: all $p>0.75$ for Fig. $3 B$, left; two-way ANOVA). In animals receiving cocaine after either saline or ifenprodil, there were no main effects of Genotype $(p=0.19)$ or Treatment $(p=0.11)$, but there was a significant Genotype $\times$ Treatment interaction $\left(\mathrm{F}_{(1,32)}=4.32, p=0.047\right.$; two-way ANOVA). In animals receiving saline before cocaine, there was a strong effect of genotype (Fig. $3 B$, right) $(p=0.02$; Holm-Sidak post hoc test); as expected, Kal7 ${ }^{\mathrm{KO}}$ mice showed a diminished place preference for cocaine (Kiraly et al., 2010b). When Wt animals were given ifenprodil before each injection of cocaine, they
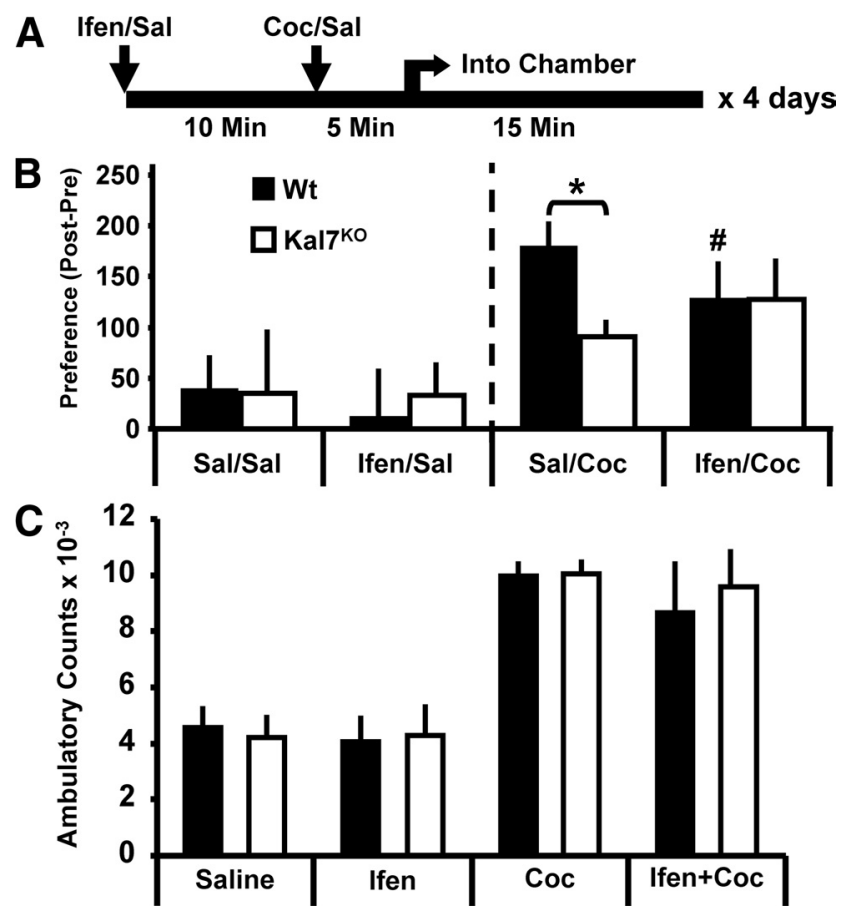

Figure 3. Blockade of NR2B subunit-containing NMDA receptors eliminates differences in cocaine-conditioned place preference response in Kal7 ${ }^{\mathrm{KO}}$ and Wt animals. $\boldsymbol{A}$, Timeline of daily injections. Cocaine (Coc) injections ( $10 \mathrm{mg} / \mathrm{kg}$ ) were preceded by ifenprodil (Ifen) injections ( 2 $\mathrm{mg} / \mathrm{kg}$, i.p.) to block NR2B subunit-containing NMDA receptors. Sal, Saline. $\boldsymbol{B}$, Left, Animals that received saline only or ifenprodil before saline showed no genotypic differences and no significant preference/aversion ( $n=3-5$ /group). $\boldsymbol{B}$, Right, In the groups receiving saline injections before cocaine injections, Kal7 ${ }^{\mathrm{K} 0}$ animals showed a robust decrease in place preference (effect of genotype within saline, ${ }^{*} p=0.02 ;$ Holm-Sidak test). In Wt animals, when ifenprodil preceded the cocaine injection there was a significant decrease in preference compared to saline pretreatment (effect of treatment within Wt, ${ }^{\#} p=0.01$ ). The genotypic difference between Wt and Kal7 ${ }^{\mathrm{KO}}$ animals was abrogated when animals were pretreated with ifenprodil (effect of genotype within ifenprodil, $p=0.61)(n=7-10 /$ group). C, Acute locomotor effects of cocaine (10 mg/kg), ifenprodil ( $2 \mathrm{mg} / \mathrm{kg})$, or both administered concomitantly. Ifenprodil alone produced no effect on locomotor activity. While cocaine produced the expected increase in locomotor activity, simultaneous injection of ifenprodil did not alter the response. There were no genotype-dependent effects in this study ( $n=4 /$ group).

showed a significant decrease in preference (effect of ifenprodil within Wt: $p=0.01$ ); in contrast, ifenprodil did not alter the response of $\mathrm{Kal}^{\mathrm{KO}}$ animals to cocaine (effect of ifenprodil within $\left.\mathrm{Kal}{ }^{\mathrm{KO}}: p=0.77\right)$. Pretreatment with ifenprodil abolished the genotypic difference between $\mathrm{Wt}$ and $\mathrm{Kal} 7{ }^{\mathrm{KO}}$ mice (Fig. $3 \mathrm{~B}$, right; effect of genotype within ifenprodil, $p=0.61$ ). While blockade of NR2B subunit-containing NMDA receptors decreased preference in Wt mice, ifenprodil treatment did not eliminate the conditioned response entirely, an effect similar to published results in mice (Pascoli et al., 2011). Our data are consistent with the hypothesis that NR2B subunit-containing NMDA receptors play an important role in cocaine-induced place preference and that the absence of Kal7 diminishes the contribution of NR2B subunitcontaining NMDA receptors to this behavior.

$\mathrm{Kal}{ }^{\mathrm{KO}}$ mice demonstrate a normal locomotor response to a wide range of acute cocaine doses (Kiraly et al., 2010b). To eliminate a potential confound due to an aberrant locomotor response to ifenprodil or to the combination of ifenprodil and cocaine, we monitored the locomotor response of $\mathrm{Wt}$ and $\mathrm{Kal}{ }^{\mathrm{KO}}$ mice to an injection of ifenprodil, cocaine, or both using a Latin square design (Benavides et al., 2007; Kiraly et al., 2010b) (Fig. 3C). Animals were given each of the four treat- 


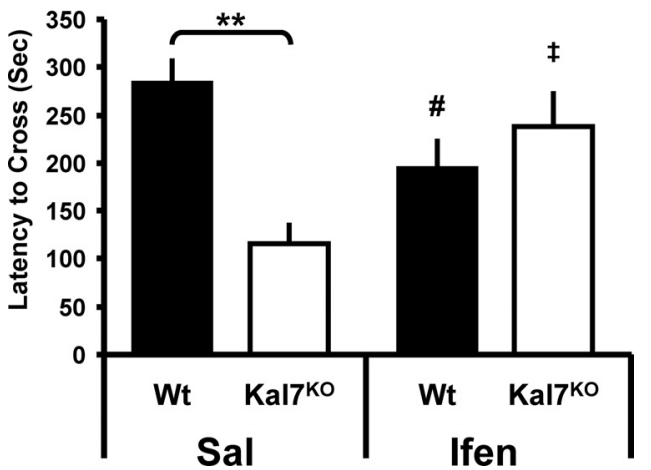

Figure 4. Blockade of NR2B subunit-containing NMDA receptors abrogates genotypic differences in passive avoidance fear conditioning. Left, In animals receiving an injection of saline (Sal) before passive avoidance conditioning, $\mathrm{Kal} 7{ }^{\mathrm{K} 0}$ animals showed significantly decreased conditioning compared to Wt mice ( ${ }^{* *} p=0.003 ;$ Holm-Sidak test). Right, In animals treated with ifenprodil (Ifen) before conditioning, the genotypic difference was eliminated $(p=0.18$ ). While $\mathrm{Wt}$ animals showed a significant decrease in conditioning with ifenprodil pretreatment (effect of treatment within Wt, ${ }^{\#} p=0.01$ ), Kal7 ${ }^{\mathrm{K} 0}$ animals exhibited a significant increase in conditioning following NR2B blockade (effect of treatment within Wt, $\left.{ }^{\ddagger} p=0.04\right)(n=$ $6-12 /$ group).

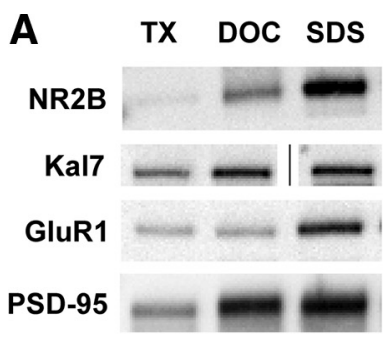

C Kal7 IP (1\% SDS)

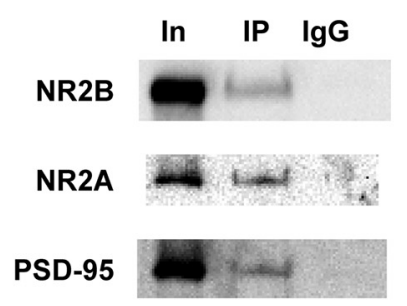

Kal7

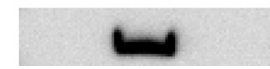

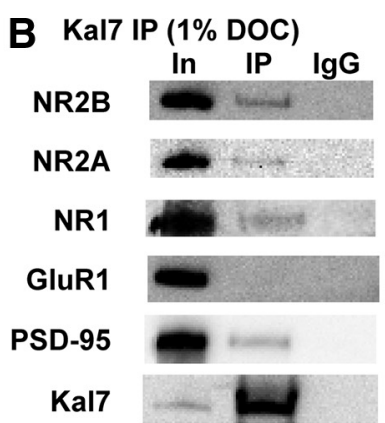

D NR2B IP (1\% DOC); pan-Kalirin WB

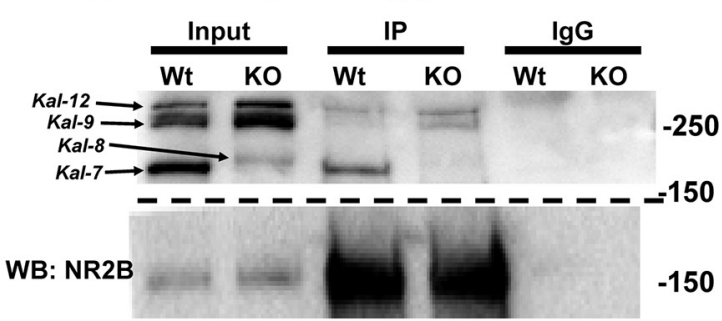

WB: Tubulin

(all $p \geq 0.64$ ). Thus, the differences noted in cocaine place preference do not reflect an altered acute behavioral response of either genotype to ifenprodil.

\section{Differences in Wt and $\mathrm{Kal}^{\mathrm{KO}}$ mouse passive avoidance behaviors are abrogated by ifenprodil}

We previously observed a deficit in the passive avoidance form of contextual fear conditioning in $\mathrm{Kal}^{\mathrm{KO}}$ animals (Ma et al., 2008b). NR2B subunit-containing NMDA receptors are known to play an essential role in fear memory formation and maintenance (Rodrigues et al., 2001; Sotres-Bayon et al., 2007). Additionally, transgenic animals engineered to overexpress NR2B showed enhanced fear conditioning and extinction behavior (Tang et al., 1999). To determine whether the Kal ${ }^{\mathrm{KO}}$ animals had an altered response to NR2B blockade, we injected animals with either saline or ifenprodil $(2 \mathrm{mg} / \mathrm{kg}) 15 \mathrm{~min}$ before training. There were no significant genotype or treatment differences in latency to cross on the training day (data not shown). The avoidance test was administered $24 \mathrm{~h}$ after conditioning (Fig. 4). While there were no main effects of genotype $(p=0.11)$ or treatment $(p=0.89)$, there was a strong Genotype $\times$ Treatment interaction $\left(\mathrm{F}\left({ }_{1,35}\right)=11.30, p=0.002\right.$; two-way ANOVA). Post hoc tests revealed a strong genotype effect within the saline $(p=$ 0.003 , Holm-Sidak test) but not in the ifenprodil-treated animals. Interestingly, while the Wt animals showed a significant decrease in conditioning (effect of ifenprodil within $\mathrm{Wt}, p=0.01$ ), the $\mathrm{Kal} 7^{\mathrm{KO}}$ animals showed a significant enhancement of conditioning with ifenprodil pretreatment (effect of ifenprodil within $\left.\mathrm{Kal}^{\mathrm{KO}}, p=0.04\right)$. Saline-treated Kal7 ${ }^{\mathrm{KO}}$ mice showed a decrease in conditioning compared to $\mathrm{Wt}$ mice that was similar to that reported previously ( $\mathrm{Ma}$ et al., 2008b). Thus, administration of ifenprodil abolished behavioral differences between Wt and Kal7 ${ }^{\mathrm{KO}}$ animals for both passive avoidance conditioning and cocaine place preference.

\section{Endogenous Kal7 and NMDA receptor complexes interact}

Based on the electrophysiological (Fig. 1), biochemical (Fig. 2). and behavioral (Figs.

Figure 5. Kal7 associates with NMDA receptor complexes in vivo. A, Solubilization of rat forebrain synaptosomal proteins with different detergents yielded different amounts of soluble NR2B, Kal7, GluR1, and PSD-95. Samples were loaded as equal percentages of the supernatant after detergent extraction; line in Kal7 sample indicates image is from a nonadjacent well of the same gel. $\boldsymbol{B}$, In samples solubilized with DOC, immunoprecipitation (IP) with the Kal7 mAb coprecipitates a small fraction of the NR2B, NR2A, NR1, and PSD-95, but no detectable GluR1. Incubation of sample with preimmune lgG showed no binding. IP came from 50-fold more sample than Input (In); recovery of Kal7 is shown in the bottom panel. C, Solubilization of synaptosomes with $1 \%$ SDS revealed coprecipitation of NMDAR subunits and PSD-95 with Kal7; Ig G controls again showed no binding. IP came from 100-fold more sample than Input; recovery of Kal7 is shown in the bottom panel. D, Synaptosomes from Wt and Kal7 ${ }^{\mathrm{KO}}$ animals were solubilized with DOC, immunoprecipitated using an NR2B antibody, and blotted for all isoforms of Kalirin. Examination of the Input sample confirmed the absence of Kal7 and increase in Kal8/9/12 in Kal7 ${ }^{\mathrm{KO}}$ animals, as reported (Ma etal., 2008b). A fraction of the Kal7 coimmunoprecipitated with NR2B in Wt extracts, as did small amounts of Kal9 and Kal12. In Kal7 ${ }^{\mathrm{K} 0}$ samples, coimmunoprecipitation of Kal9 and Kal12 was more apparent. Western blotting (WB) for tubulin confirmed equal loading in the input lanes, and lgG controls confirmed the absence of nonspecific binding; recovery of NR2B is shown in the middle panel. Similar results were observed in triplicate and quadruplicate $(\boldsymbol{B}, \boldsymbol{C})$ or duplicate $(\boldsymbol{D})$ samples.

3. 4) findings that suggest a specific role for Kal7 in NR2B subunit-containing NMDA receptor localization and function, we investigated the possibility that Kal7 and NR2B interact directly. To explore this possibility, synaptosomes were solubilized using three different protocols. Given that the PSD is a complex and highly interconnected piece of machinery, the method used to solubilize PSD proteins is a critical determinant of the interactions that can be measured. As shown in Figure $5 A$, the three detergent condi-

ments in a randomized order over the course of $4 \mathrm{~d}$. While the expected significant effect of cocaine was observed $\left(\mathrm{F}_{(1,31)}=\right.$ $50.44, p<0.001$; three-way ANOVA), there were no effects of genotype ( $p=0.79)$, ifenprodil $(p=0.46)$, or any interactions tions tested solubilized different amounts of NR2B, Kal7, GluR1, and PSD-95. In the least stringent detergent protocol ( $1 \%$ TX-100/0.1\% SDS; TX), very little NR2B or PSD-95 was solubilized, while substantial amounts of Kal7 and GluR1 
were recovered from the supernatant. DOC solubilization increased the recovery of NR2B and PSD-95 from the soluble fraction but had relatively little effect on the recovery of Kal7 or GluR1. Solubilization with $1 \%$ SDS (at room temperature) further increased the solubilization of NR2B and GluR1.

Based on its ability to solubilize NR2B and Kal7 and the fact that it has been widely used for examining protein-protein interactions in the PSD (Wyszynski et al., 2002; Collins et al., 2006; Al-Hallaq et al., 2007) we chose the DOC protocol as our primary method of solubilization for coimmunoprecipitation experiments. Using this protocol, immunoprecipitation of Kal7 led to coprecipitation of a small but significant amount of NR2B, NR2A, and NR1 as well as PSD-95 (Fig. $5 B$ ), but not the AMPA receptor subunit GluR1 (Fig. 5B). Coprecipitation of both NR2B and NR2A from synaptosomes was expected, as $30-40 \%$ of endogenous NMDA receptors are thought to be triheteromeric $\left(\mathrm{NR}_{2} / \mathrm{NR} 2 \mathrm{~A} /\right.$ NR2B) (Al-Hallaq et al., 2007). To determine the stability of the Kal7NMDAR interactions, we performed one set of experiments using more stringent solubilization conditions (1\% SDS) (Fig. 5C). Following SDS extraction, immunoprecipitation of Kal7 still coprecipitated NMDA receptor subunits NR2B and NR2A as well as PSD95. Under these same conditions, immunoprecipitation of NR2B resulted in robust coprecipitation of NR2A, indicating that NMDA receptor complexes remained intact (data not shown). Maintenance of the Kal7-NMDAR interaction, despite strong detergent application, indicates that the interaction is a stable one.

To verify the Kal7-NMDAR interaction, we asked whether NR2B antibody coprecipitated Kal7 (Fig. 5D); using a pan-Kalirin antibody, coprecipitation of Kal7 was demonstrated. In addition, larger isoforms of Kalirin were detected. Kal $7{ }^{\mathrm{KO}}$ mice were engineered to lack Kal7 while still expressing the larger isoforms; as reported previously, levels of Kal8, Kal9, and Kal12 are increased in Kal7 $7^{\mathrm{KO}}$ animals (Fig. 5D, KO Input) (Ma et al., 2008b). NR2B immunoprecipitation from Kal7 ${ }^{\mathrm{KO}}$ synaptosomes revealed coprecipitation of Kal9 and Kal12 (Fig. 5D, IP). Unlike NR2B and Kal7, Kal9 and Kal12 lack a PDZ binding motif (Al-Hallaq et al., 2007). Our findings indicate that the Kalirin/NR2B subunit interaction is not solely dependent on PDZ domain binding.

\section{The KalPH1 domain of Kal7 specifically interacts with a membrane-proximal region of NR2B}

To determine whether Kalirin and NR2B interact directly and to map sites of interaction, we turned to non-neuronal cells. pEAK Rapid cells, a HEK-293 derivative, do not express PSD-95 or other MAGUK proteins (Fig. 6A). In cells cotransfected with vectors encoding Kal7, NR1, and either NR2B or NR2A, Kal7 monoclonal antibody beads coprecipitated NR2B, but not NR2A
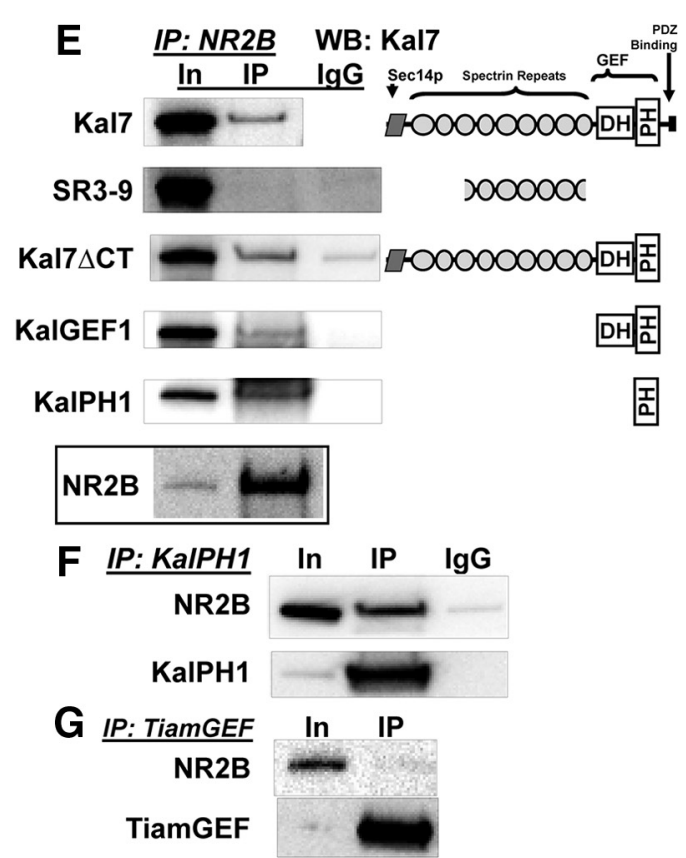

Figure 6. KalPH1 interacts with NR2B. A, pEAK Rapid cell ( $\mathrm{pE}$ ) and mouse brain (Br) lysate (10 or $20 \mu \mathrm{g}$ of protein) were blotted is sufficient for Kal7 coprecipitation with NR2B. Recovery of NR2B is shown in the bottom panel and lgG controls are indicated. WB NR2B. Samples for $\boldsymbol{F}$ and $\boldsymbol{G}$ were loaded as $\operatorname{Input}(1): I P(90)$, with recoveries shown in the bottom panels. IgG controls showed no background staining; each of these IPs was performed on 3-7 sample preparations with similar results each time.

(Fig. 6B). Immunoprecipitation of NR2B (Fig. 6C), but not NR2A (Fig. 6D), from these same lysates led to coprecipitation of Kal7. The fact that coimmunoprecipitation of Kal7 and NR2B took place outside of the meshwork of the PSD and was specific for NR2B suggests that Kal7 may interact directly with NR2B.

Kal7 is a large protein; to identify the region responsible for its interaction with NR2B, vectors encoding fragments of Kalirin were expressed along with NR1 and NR2B (Fig. $6 E$ ). A fragment that begins in spectrin repeat 3 and ends in spectrin repeat 9 (SR3-9) and has been shown to interact with inducible nitric oxide synthase (iNOS; Ratovitski et al., 1999) and DISC-1 (Hayashi-Takagi et al., 2010) did not coprecipitate with the NR2B subunit. Kal7 $\Delta C T$, which lacks the 60 C-terminal residues of Kal7, including the PDZ binding motif, coprecipitated with NR2B, as did the GEF1 domain. Rho-GEF domains consist of a catalytic Dbl homology (DH) domain followed by a pleckstrin homology (PH) domain (Rossman et al., 2005). When expressed alone, a KalPH1-GFP fusion protein interacted with NR2B (Fig. $6 E$ ). To verify this, we coexpressed KalPH1-GFP and NR1/NR2B and used an antibody to GFP to look for an interaction; immunoprecipitation of KalPH1-GFP led to coprecipitation of NR2B (Fig. 6 F). Interestingly, the $\mathrm{PH} 2$ domain of Kalirin, which is only present in the larger isoforms, also coprecipitated NR2B (data not shown). To determine whether this interaction were specific to Kalirin, we cotransfected NR1/NR2B and vector 


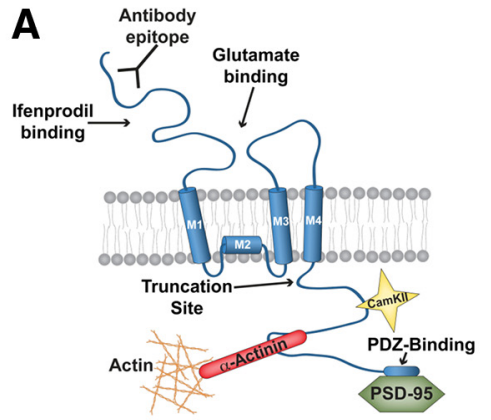

B

$$
\begin{array}{r}
\text { IP: Kal7 } \\
\hline \text { NR2B } \\
\text { Kal7 }
\end{array}
$$

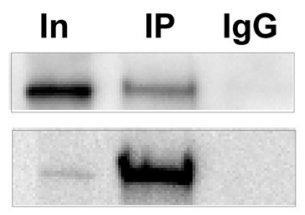

C IP: $\triangle N R 2 B$

Kal7

$\triangle \mathrm{NR2B}$

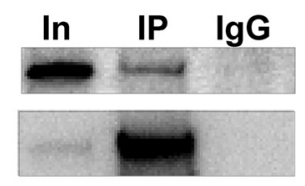

D

IP: KalPH1
$\Delta \mathrm{NR2B}$
KalPH1

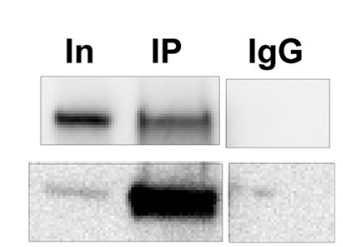

$E$

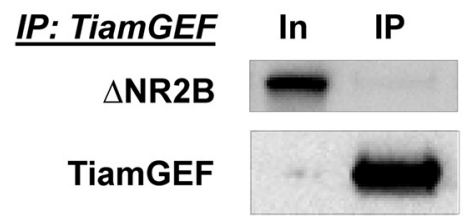

Figure 7. Interaction between KalPH1 and NR2B involves a membrane proximal intracellular segment of NR2B. A, Diagram of the NR2B subunit showing the C terminus of $\triangle$ NR2B (residues 1-861 of NR2B) (Foster et al., 2010) and the antibody binding epitope. Sites known to interact with specific proteins are indicated. $\boldsymbol{B}$, pEAK Rapid cells cotransfected with vectors encoding Kal7 and $\Delta N R 2 B$ were immunoprecipitated with Kal7 $\mathrm{mAb}$ beads; coprecipitated $\triangle N$ N2B was visualized using monoclonal antibody to the extracellular domain. All samples shown in this figure were cotransfected with NR1 and loaded Input (In)(1):IP(90); recoveries are shown in the bottom panels. IP, Immunoprecipitation. C, Immunoprecipitation of $\triangle N R 2 B$ coprecipitated Kal7, which was visualized with Kal7 polyclonal antibody. D, Cells cotransfected with vectors encoding KaIPH1-GFP and $\triangle$ NR2B were immunoprecipitated with rabbit polyclonal antibody to GFP; the coprecipitated $\triangle$ NR2B was visualized using monoclonal antibody to the extracellular domain, indicating that this interaction is specific to the KalPH1 domain. $\boldsymbol{E}$, Cells cotransfected with vectors encoding HA-tagged TiamGEF and $\triangle N R 2 B$ were immunoprecipitated with polyclonal antibody to HA; TiamGEF does not coprecipitate $\triangle N R 2 B$. IgG controls showed no background binding. All IPs were repeated at least four times with similar results.

encoding the GEF domain of Tiam1 (TiamGEF), another Rac GEF localized to the PSD (Tolias et al., 2005). Immunoprecipitation of TiamGEF did not result in coprecipitation of the NR2B subunit (Fig. 6G).

We next mapped the region of the NR2B subunit that interacts with Kal-PH1; NR2B contains a large extracellular domain that begins with the $\mathrm{N}$-terminal regulatory domain where ifenprodil and other allosteric modulators bind and is followed by the glutamate binding domain (Fig. 7A). Three transmembrane domains and a nonpenetrant membrane domain form the ion channel; the $\sim 80 \mathrm{kDa}$ intracellular C-terminal domain of NR2B interacts with multiple cytosolic proteins, including CaMKII (Barria and Malinow, 2005) and $\alpha$-actinin (Wyszynski et al., 1997; Cull-Candy and Leszkiewicz, 2004), and terminates with a PDZ-binding motif known to interact with PSD-95 (Lau and Zukin, 2007). We first tested $\Delta$ NR2B, which terminates shortly after the final transmembrane domain (Foster et al., 2010). When Kal7, NR1 and $\Delta$ NR2B were coexpressed, the Kal7 antibody beads coprecipitated $\Delta$ NR2B (Fig. $7 B$ ). Immunoprecipitation of $\Delta$ NR2B with antibody directed to its extracellular $\mathrm{N}$-terminal domain coprecipitated Kal7 (Fig. 7C). To ensure that this was the same interaction we were seeing before, we cotransfected KalPH1-GFP, NR1, and $\Delta$ NR2B; coprecipitation of KalPH1-GFP and $\triangle$ NR2B was observed (Fig. 7D). As before, the TiamGEF domain and $\Delta$ NR2B did not coprecipitate (Fig. 7E).
KalPH1 interacts directly with the final juxtamembrane region of NR2B

The intracellular region of $\Delta \mathrm{NR} 2 \mathrm{~B}$ is limited to three short sequences; since KalPH1-GFP interacts with NR2B but not with NR2A, we compared their sequences in these three regions (Fig. $8 A$ ). Five of the nineteen residues in the $\mathrm{M} 1 \rightarrow \mathrm{M} 2$ loop differ while none of the eleven residues in the $\mathrm{M} 2 \rightarrow \mathrm{M} 3$ loop differ (Fig. $8 A$; loop diagrams in Fig. 7A). Eight of the seventeen residues that follow $\mathrm{M} 4$ in $\triangle \mathrm{NR} 2 \mathrm{~B}$ $(\mathrm{M} 4 \rightarrow$ End) differ (Fig. $8 A$ ). To test the $\mathrm{M} 4 \rightarrow$ End region, an NR2B juxtamembrane peptide (2B-JM) was synthesized and linked to AffiGel beads. Lysates of pEAK Rapid cells expressing Kal7, KalPH1-GFP, SR3-9, or GFP only were incubated with 2B-JM beads or control (no peptide) beads. Kal7 and KalPH1GFP bound to 2B-JM beads but not to control beads (Fig. 8B). KalPH1-GFP lysates were also incubated with $\beta$-endorphin beads; no binding was seen, with this positively charged peptide (data not shown). Neither SR3-9 nor GFP bound to the 2B-JM beads. Incubation of 2B-JM beads with lysates from cells expressing KalPH2 revealed a similar interaction with KalPH2 (data not shown). To determine whether binding to the 2B-JM beads was saturated, we incubated increasing concentrations of KalPH1-GFP lysate with a fixed amount of beads. As the concentration of lysate was increased, we saw a plateau in binding (Fig. $8 \mathrm{C}$ ). Finally, to determine whether the juxtamembrane region of NR2B could interact with endogenous Kal7, we incubated 2B-JM beads with mouse brain synaptosomes solubilized with TX-100 or DOC. The 2B-JM beads bound Kal7 solubilized with either detergent, but control beads did not (Fig. $8 D$ ). From these experiments we can conclude that there is a specific and stable interaction between the $\mathrm{PH}$ domains of Kalirin and the juxtamembrane region at the $\mathrm{C}$ terminus of NR2B (Fig. $8 E$ ).

To confirm that the $2 \mathrm{~B}-\mathrm{JM}$ region was in fact the region of $\Delta$ NR2B responsible for its interaction with KalPH1-GFP, we constructed three $\Delta \mathrm{NR} 2 \mathrm{~B}$ mutants. The $2 \mathrm{~B}-\mathrm{JM}$ region of $\Delta \mathrm{NR} 2 \mathrm{~B}$ was replaced by the corresponding region of NR2A to generate $\Delta \mathrm{NR} 2 \mathrm{~B} \rightarrow 2 \mathrm{~A}$. $\Delta \mathrm{NR} 2 \mathrm{~B}$ Stub stopped shortly after the final transmembrane domain of NR2B. In $\triangle \mathrm{NR} 2 \mathrm{~B}$ GAGA, the 2B-JM region was replaced with a repeating sequence of Gly-Ala residues. pEAK Rapid cells were transfected with NR1, KalPH1-GFP, and $\triangle \mathrm{NR} 2 \mathrm{~B}$ or one of these three mutant constructs. As seen previously, immunoprecipitation of KalPH1-GFP strongly coprecipitated $\triangle$ NR2B (Fig. 9A). For each of the three mutants, coprecipitation of $\triangle N R 2 B$ with KalPH1-GFP was reduced to levels just above the IgG control (Fig. 9B-D). Importantly, each $\Delta$ NR2B mutant coprecipitated NR1 as effectively as $\Delta \mathrm{NR} 2 \mathrm{~B}$, indicating that they were capable of forming receptor complexes (data not shown). Thus, the 2B-JM region of $\triangle \mathrm{NR} 2 \mathrm{~B}$ is essential for the interaction of KalPH1 and $\Delta$ NR2B. 


\section{Discussion}

NR2B function is altered when Kal7 is absent

Purified PSDs from the cortices of Kal7 ${ }^{\mathrm{KO}}$ animals contain slightly reduced levels of NR2B (Ma et al., 2008b). Here, we demonstrate that this decrease results in altered synaptic physiology. Kal7 ${ }^{\mathrm{KO}}$ animals have an overall decrease in the ratio of their NMDA/AMPA receptor currents, largely due to a decrease in current conducted via NR2B subunit-containing receptors (Fig. 1). Additionally, we demonstrate that this decrease is due to a decrease in cell surface localization of NR2B subunitcontaining NMDA receptors (Fig. 2). Given that $\sim 1 / 3$ of NMDA receptors are thought to be triheteromeric and that surface levels of NR2A are unaltered in $\mathrm{Kal} 7^{\mathrm{KO}}$ mice, NR1/NR2B diheteromeric receptors may be especially sensitive to the absence of Kal7. Interestingly, ifenprodil more potently inhibits NR1/NR2B diheteromeric receptors (Hatton and Paoletti, 2005). Localization of NR2B subunit-containing receptors to synapses is essential for induction of long-term potentiation, and neurons overexpressing NR2B show enhanced potentiation (Tang et al., 1999; Akashi et al., 2009). More recent studies have shown that NR2B is essential because of the many proteins recruited to the synapse via their interactions with its cytosolic tail (Foster et al., 2010). The ability of NR2B to localize CaMKII and its other binding partners directly to the source of large calcium currents seems to be critical for LTP induction (Barria and Malinow, 2005). Decreased synaptic NR2B subunit-containing receptor levels and currents may explain why Kal7 ${ }^{\mathrm{KO}}$ animals exhibit significantly impaired NMDA receptor-dependent LTP (Ma et al., 2008b) (F. LemtiriChlieh, D. D. Kiraly, L. Zhao, B. A. Eipper, R. E. Mains, E. S. Levine, unpublished observations).

Smaller spines and spines where presynaptic input has been blocked have greater accumulations of NR2B-containing receptors than larger spines or those receiving stronger inputs (Sobczyk et al., 2005; Lee et al., 2010). Additionally, smaller spines are more easily potentiated and demonstrate more robust and pronounced increases in dendritic head size in response to stimulation (Matsuzaki et al., 2004; Bourne and Harris, 2007). Numerous studies have suggested that synapses expressing higher levels of NR2B have a lower threshold for potentiation (Lau and Zukin, 2007). Given this, it seems likely that localization of NR2B-containing receptors to newly developing synapses is a key to ensuring synapse stabilization and maturation. Kal7 has been implicated in the formation and stabilization of new dendritic spines both in vitro and in vivo (Ma et al., 2008a,b). As shown here, Kal7 ${ }^{\mathrm{KO}}$ mice are deficient in NR2B subunitcontaining receptor signaling and surface localization (Figs. 1,2). If NR2B is an important component in stabilizing newly formed spines, this may partially explain how Kal7 expression leads to increases in spine density.
B

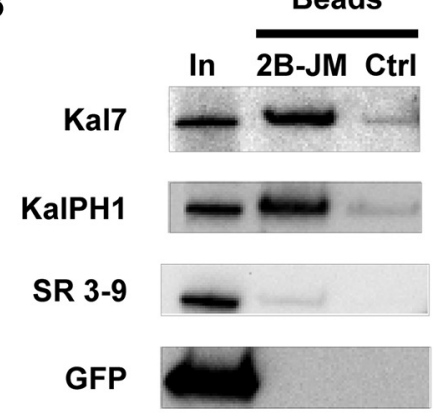

D

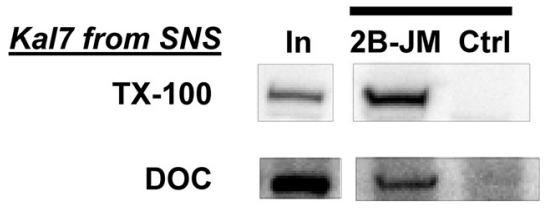

Figure 8. Interaction of KalPH1 with the juxtamembrane region of NR2B $A$, Clustal analysis comparing intracellular regions of

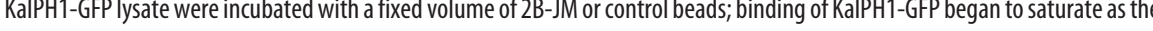
solubilized with $1 \%$ TX-100 or 1\% DOC (dialyzed). Kal7 solubilized in either way bound to 2B-JM beads but not to control beads. Pulldowns for $\boldsymbol{B}$ and $\boldsymbol{D}$ were performed in duplicate or triplicate with similar results.

A

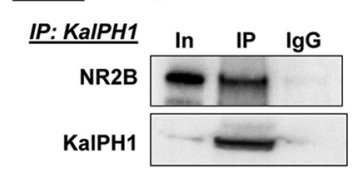

C Stub: LFYWKLRAG

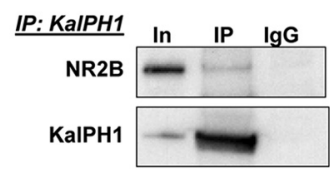

B 2 B $\rightarrow 2 A:$ LFYWKLRFCFTGVCSDRPGLL

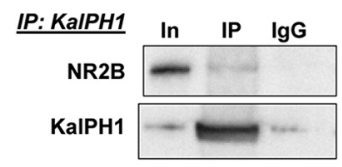

D GAGA: LFYWKLRAGAGAGAAGAGAGA

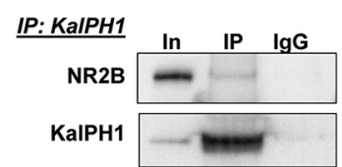

Figure 9. Mutation of the 2B-JM region decreases KaIPH1- $\triangle$ NR2B coprecipitation. The sequences of the final juxtamembrane region of $\Delta N R 2 B(A)$, the NR2B $\rightarrow 2 A$ mutant $(B)$, the Stub mutant $(\boldsymbol{C})$ and the GAGA mutant $(\boldsymbol{D})$ are shown (black text) with the preceding four amino acids (gray text). Cells cotransfected with NR1, each $\triangle N R 2 B$ construct, and KaIPH1-GFP were immunoprecipitated with antibody to GFP or control lgG. Coprecipitation of $\Delta N R 2 B$ was observed as shown in previous figures; each mutation reduced coprecipitation to background levels. Images for $\boldsymbol{A}-\boldsymbol{C}$ were all from the same gel; images for $\boldsymbol{D}$ were from a different gel exposed for the same time. $\triangle N R 2 B$ and all mutants equally coprecipitated NR1, indicating the formation of stable receptor complexes (data not shown). In, Input; IP, immunoprecipitation.

\section{Behavioral differences between $\mathrm{Wt}$ and $\mathrm{Kal} 7^{\mathrm{KO}}$ animals are} abrogated by ifenprodil

One of the most striking deficits observed in Kal $7^{\mathrm{KO}}$ mice is a decrease in conditioned place preference for cocaine (Kiraly et al., 2010b). The circuitry involved in this response is complex and includes the striatum, prefrontal cortex, and ventral tegmental area, with roles for dopaminergic, glutamatergic, GABAergic, and cholinergic transmission (Hyman et al., 2006; Kauer and Malenka, 2007; 
Williams and Adinoff, 2008; Kalivas, 2009). NR2B subunitcontaining NMDA receptor function is known to be necessary for cocaine and morphine place conditioning (Ma et al., 2006; Pascoli et al., 2011). In Kal7 ${ }^{\mathrm{KO}}$ animals, loss of the Kal7/NR2B interaction and subsequent reduction in NR2B-containing receptor-mediated plasticity may underlie this behavioral deficit. We thus hypothesized that blocking NR2B-containing receptors would reproduce this deficit in Wt animals but have less effect in $\mathrm{Kal} 7{ }^{\mathrm{KO}}$ mice. Consistent with this prediction, ifenprodil administration eliminated the difference between $\mathrm{Kal} 7^{\mathrm{KO}}$ and Wt mice, although mice of both genotypes continued to exhibit a preference for cocaine (Fig. 3). This is consistent with the fact that this behavioral response is not entirely dependent on NR2B-containing NMDA receptors.

Similar to the conditioned place preference effect, we had seen decreases in passive avoidance fear conditioning in $\mathrm{Kal}{ }^{\mathrm{KO}}$ animals (Ma et al., 2008b). When Wt and $\mathrm{Kal}^{\mathrm{KO}}$ animals were given ifenprodil before conditioning, this genotypic difference was also abolished (Fig. 4). NR2B-containing NMDA receptor function has been shown to be crucial for consolidation of fear-conditioning memories (Tang et al., 1999; Rodrigues et al., 2001). Interestingly, ifenprodil pretreatment had distinctly different effects in $\mathrm{Wt}$ and $\mathrm{Kal}^{\mathrm{KO}}$ mice, with reduced fear conditioning in $\mathrm{Wt}$ mice and increased fear conditioning in $\mathrm{Kal}{ }^{\mathrm{KO}}$ mice. Region-specific responses to elimination of Kal7 may be a factor; for example, while spine density is reduced in $\mathrm{Kal} 7{ }^{\mathrm{KO}}$ versus $\mathrm{Wt}$ CA1 hippocampal pyramidal neurons under baseline conditions (Ma et al., 2008b), basal spine density is unaltered in the $\mathrm{Kal} 7^{\mathrm{KO}}$ nucleus accumbens (Kiraly et al., 2010b).

$\mathrm{Kal} 7^{\mathrm{KO}}$ mice may have compensatory developments that allow their function to rely more heavily on NR2A subunit-containing NMDA receptors, which are expressed at normal levels (Fig. 2), or other non-NMDA receptor-dependent forms of plasticity. Mice lacking NR2A subunits have reduced LTP as well, indicating that NMDA receptor-mediated LTP is not solely dependent on NR2B (Sakimura et al., 1995). Additionally, non-NMDA receptordependent forms of LTP have been described (Cavus and Teyler, 1998). Interestingly, recent electrophysiological experiments on $\mathrm{Kal} 7^{\mathrm{KO}}$ mice indicate that they exhibit impaired NMDA receptordependent LTP, but normal non-NMDA receptor-mediated LTP (F. Lemtiri-Chlieh, D. D. Kiraly, L. Zhao, B. A. Eipper, R. E. Mains, E. S. Levine, unpublished observations). Increased reliance on these alternate pathways in $\mathrm{Kal} 7^{\mathrm{KO}}$ mice may explain why inhibition of NR2B-containing receptors does not further accentuate their behavioral deficits.

\section{Binding of Kal7 to NR2B-containing NMDA receptors is stable and specific}

The PSD is an intricate complex of hundreds of proteins (Sheng and Hoogenraad, 2007); proper pairwise connections among specific proteins in this network are critical for synaptic function. Both Kal7 and NMDA receptors interact directly with multiple PSD constituents, including multiple PDZ domain-containing proteins. The C-terminal PDZ binding motif of Kal7 interacts with PSD-95 in a way that decreases its catalytic activity (Penzes et al., 2001a) and with afadin (AF-6) in a way that helps anchor it in the PSD (Xie et al., 2008). Interactions of the C terminus of NR2B with PSD-95 and SAP-97 are critical for stabilizing synaptic NMDA receptors (Niethammer et al., 1996; Roche et al., 2001). It is currently not clear whether Kal7 and NR2B can bind simultaneously to PSD-95, which has three PDZ domains. We show here that Kalirin and NR2B-containing NMDA receptors interact directly in a way that is not dependent on PDZ binding.
In addition to NR2B, the first $\mathrm{PH}$ domain of Kal7 binds to TrkA, the high affinity NGF receptor (Chakrabarti et al., 2005).

NMDA receptors exist as part of huge macromolecular complexes in the PSD, reflective of direct and indirect interactions with receptors, scaffolding proteins, and enzymes (Husi and Grant, 2001). Interestingly, the interactions of Kalirin with the NR2B subunit involve its juxtamembrane region (Figs. 7-9), placing Kalirin in an excellent position to modulate channel function or respond to calcium influx through the receptor. A number of other proteins interact with the juxtamembrane regions of specific NMDA receptor subunits. Calmodulin binds the $\mathrm{C}$ terminus of the NR1 subunit in a calcium-dependent manner and causes channel inactivation (Ehlers et al., 1996). The interaction of calmodulin with the NR1 subunit seems to be directly competitive with the actin binding protein $\alpha$-actinin, which may help crosslink these receptors to the actin cytoskeleton and stabilize them in the synapse (Wyszynski et al., 1997). Additionally, both the NR1 and NR2B subunits have AP-2 binding sites in their juxtamembrane C-terminal regions, and binding of AP-2 leads to dynamin-dependent receptor internalization (Scott et al., 2004). The 2B-JM peptide used to pull down Kal7 and KalPH1-GFP (Figs. 8, 9) contains part of this AP-2 binding motif, and Kalirin may affect surface localization of NR2B-containing receptors by competing with AP-2. BLAST searches of the $2 \mathrm{~B}-\mathrm{JM}$ region of the NR2B subunit, which is fully conserved in mouse, rat, chimp, and human, identify the corresponding region of NR2A as the closest match (9/17 residues). Replacing the $2 \mathrm{~B}-\mathrm{JM}$ region of $\Delta \mathrm{NR} 2 \mathrm{~B}$ with the corresponding sequence from NR2A eliminated its interaction with KalPH1-GFP. In addition to the 2B-JM region, the full-length NR2B subunit may have additional interactions with Kal7.

Kalirin activates Rac1, a GTPase known to mediate actin rearrangement (Penzes et al., 2001b; Hotulainen and Hoogenraad, 2010). Interactions of NMDA receptors with the actin cytoskeleton are known to be essential for NMDA receptor function and localization (Rosenmund and Westbrook, 1993; Allison et al., 1998). Both spectrin and $\alpha$-actinin bind to NMDA receptors, linking them to the actin cytoskeleton (Wyszynski et al., 1997; Wechsler and Teichberg, 1998). Kal7 is not the only Rho-GEF known to bind to NMDA receptors. The Rac-GEF Tiam-1 binds to the NR1 subunit and is critical for NMDA-induced spine dynamics in neuronal cultures (Tolias et al., 2005). RasGRF1, a dual Ras- and Rac-GEF, binds directly to NR2B (Krapivinsky et al., 2003), and RasGRF1 knock-out mice show decreases in cocaine place preference, as do Kal7 ${ }^{\mathrm{KO}}$ mice (Fasano et al., 2009). The activity of both Tiam-1 and RasGRF1 is modulated by calcium and/or calcium-calmodulin-dependent kinases (Fleming et al., 1999; Tian et al., 2004; Schmitt et al., 2005; Tolias et al., 2005; Tian and Feig, 2006). By being directly coupled to NMDA receptors, these GEFs are uniquely positioned to transduce calciumdependent signals. We have directly identified multiple CaMKII sites in Kal7 (Kiraly et al., 2011); these sites are distinct from the putative CaMKII site previously identified through indirect means but are consistent with a role for calcium in controlling Kal7 signaling. Given the rapid (seconds $\rightarrow$ minutes) time course over which NMDA receptor-dependent changes in spine size occur (Murakoshi et al., 2011), GEF interactions with NMDA receptors may be critical for morphological plasticity.

\section{References}

Akashi K, Kakizaki T, Kamiya H, Fukaya M, Yamasaki M, Abe M, Natsume R, Watanabe M, Sakimura K (2009) NMDA receptor GluN2B (GluR epsilon $2 / \mathrm{NR} 2 \mathrm{~B}$ ) subunit is crucial for channel function, postsynaptic macro- 
molecular organization, and actin cytoskeleton at hippocampal CA3 synapses. J Neurosci 29:10869-10882.

Al-Hallaq RA, Conrads TP, Veenstra TD, Wenthold RJ (2007) NMDA diheteromeric receptor populations and associated proteins in rat hippocampus. J Neurosci 27:8334-8343.

Allison DW, Gelfand VI, Spector I, Craig AM (1998) Role of actin in anchoring postsynaptic receptors in cultured hippocampal neurons: differential attachment of NMDA versus AMPA receptors. J Neurosci 18:2423-2436.

Barria A, Malinow R (2005) NMDA receptor subunit composition controls synaptic plasticity by regulating binding to CaMKII. Neuron 48:289-301.

Benavides DR, Quinn JJ, Zhong P, Hawasli AH, DiLeone RJ, Kansy JW, Olausson P, Yan Z, Taylor JR, Bibb JA (2007) Cdk5 modulates cocaine reward, motivation, and striatal neuron excitability. J Neurosci 27: 12967-12976.

Borjigin J, Nathans J (1994) Insertional mutagenesis as a probe of rhodopsin's topography, stability, and activity. J Biol Chem 269:14715-14722.

Boudreau AC, Wolf ME (2005) Behavioral sensitization to cocaine is associated with increased AMPA receptor surface expression in the nucleus accumbens. J Neurosci 25:9144-9151.

Bourne J, Harris KM (2007) Do thin spines learn to be mushroom spines that remember? Curr Opin Neurobiol 17:381-386.

Caldwell BD, Darlington DN, Penzes P, Johnson RC, Eipper BA, Mains RE (1999) The novel kinase peptidylglycine alpha-amidating monooxygenase cytosolic interactor protein 2 interacts with the cytosolic routing determinants of the peptide processing enzyme peptidylglycine alphaamidating monooxygenase. J Biol Chem 274:34646-34656.

Carlisle HJ, Kennedy MB (2005) Spine architecture and synaptic plasticity. Trends Neurosci 28:182-187.

Cavus I, Teyler TJ (1998) NMDA receptor-independent LTP in basal versus apical dendrites of CA1 pyramidal cells in rat hippocampal slice. Hippocampus 8:373-379.

Chakrabarti K, Lin R, Schiller NI, Wang Y, Koubi D, Fan YX, Rudkin BB, Johnson GR, Schiller MR (2005) Critical role for Kalirin in nerve growth factor signaling through TrkA. Mol Cell Biol 25:5106-5118.

Clarke RJ, Johnson JW (2008) Voltage-dependent gating of NR1/2B NMDA receptors. J Physiol 586:5727-5741.

Collins MO, Husi H, Yu L, Brandon JM, Anderson CN, Blackstock WP, Choudhary JS, Grant SG (2006) Molecular characterization and comparison of the components and multiprotein complexes in the postsynaptic proteome. J Neurochem 97 [Suppl 1]:16-23.

Cull-Candy SG, Leszkiewicz DN (2004) Role of distinct NMDA receptor subtypes at central synapses. Sci STKE 2004:re16.

Dunah AW, Wyszynski M, Martin DM, Sheng M, Standaert DG (2000) alpha-actinin-2 in rat striatum: localization and interaction with NMDA glutamate receptor subunits. Brain Res Mol Brain Res 79:77-87.

Ehlers MD, Zhang S, Bernhadt JP, Huganir RL (1996) Inactivation of NMDA receptors by direct interaction of calmodulin with the NR1 subunit. Cell 84:745-755.

Fasano S, D'Antoni A, Orban PC, Valjent E, Putignano E, Vara H, Pizzorusso T, Giustetto M, Yoon B, Soloway P, Maldonado R, Caboche J, Brambilla R (2009) Ras-guanine nucleotide-releasing factor 1 (Ras-GRF1) controls activation of extracellular signal-regulated kinase (ERK) signaling in the striatum and long-term behavioral responses to cocaine. Biol Psychiatry 66:758-768.

Ferraro F, Ma XM, Sobota JA, Eipper BA, Mains RE (2007) Kalirin/Trio Rho guanine nucleotide exchange factors regulate a novel step in secretory granule maturation. Mol Biol Cell 18:4813-4825.

Fleming IN, Elliott CM, Buchanan FG, Downes CP, Exton JH (1999) $\mathrm{Ca}^{2+}$ calmodulin-dependent protein kinase II regulates Tiam1 by reversible protein phosphorylation. J Biol Chem 274:12753-12758.

Foster KA, McLaughlin N, Edbauer D, Phillips M, Bolton A, ConstantinePaton M, Sheng M (2010) Distinct roles of NR2A and NR2B cytoplasmic tails in long-term potentiation. J Neurosci 30:2676-2685.

Haseneder R, Kratzer S, Kochs E, Höfelmann D, Auberson Y, Eder M, Rammes G (2009) The xenon-mediated antagonism against the NMDA receptor is non-selective for receptors containing either NR2A or NR2B subunits in the mouse amygdala. Eur J Pharmacol 619:33-37.

Hatton CJ, Paoletti P (2005) Modulation of triheteromeric NMDA receptors by N-terminal domain ligands. Neuron 46:261-274.

Hayashi-Takagi A, Takaki M, Graziane N, Seshadri S, Murdoch H, Dunlop AJ, Makino Y, Seshadri AJ, Ishizuka K, Srivastava DP, Xie Z, Baraban JM,
Houslay MD, Tomoda T, Brandon NJ, Kamiya A, Yan Z, Penzes P, Sawa A (2010) Disrupted-in-Schizophrenia 1 (DISC1) regulates spines of the glutamate synapse via Rac1. Nat Neurosci 13:327-332.

Hotulainen P, Hoogenraad CC (2010) Actin in dendritic spines: connecting dynamics to function. J Cell Biol 189:619-629.

Hung AY, Futai K, Sala C, Valtschanoff JG, Ryu J, Woodworth MA, Kidd FL, Sung CC, Miyakawa T, Bear MF, Weinberg RJ, Sheng M (2008) Smaller dendritic spines, weaker synaptic transmission, but enhanced spatial learning in mice lacking Shank1. J Neurosci 28:1697-1708.

Husi H, Grant SG (2001) Isolation of 2000-kDa complexes of N-methyl-Daspartate receptor and postsynaptic density 95 from mouse brain. J Neurochem 77:281-291.

Hyman SE, Malenka RC, Nestler EJ (2006) Neural mechanisms of addiction: the role of reward-related learning and memory. Annu Rev Neurosci 29:565-598.

Kalivas PW (2009) The glutamate homeostasis hypothesis of addiction. Nat Rev Neurosci 10:561-572.

Kauer JA, Malenka RC (2007) Synaptic plasticity and addiction. Nat Rev Neurosci 8:844-858.

Kerchner GA, Nicoll RA (2008) Silent synapses and the emergence of a postsynaptic mechanism for LTP. Nat Rev Neurosci 9:813-825.

Kiraly DD, Eipper-Mains JE, Mains RE, Eipper BA (2010a) Synaptic plasticity, a symphony in GEF. ACS Chem Neurosci 1:348-365.

Kiraly DD, Ma XM, Mazzone CM, Xin X, Mains RE, Eipper BA (2010b) Behavioral and morphological responses to cocaine require Kalirin-7. Biol Psychiatry 68:249-255.

Kiraly DD, Stone KL, Colangelo CM, Abbott T, Wang Y, Mains RE, Eipper BA (2011) Identification of Kalirin-7 as a potential post-synaptic density signaling hub. J Proteome Res 10:2828-2841.

Krapivinsky G, Krapivinsky L, Manasian Y, Ivanov A, Tyzio R, Pellegrino C, Ben-Ari Y, Clapham DE, Medina I (2003) The NMDA receptor is coupled to the ERK pathway by a direct interaction between NR2B and RasGRF1. Neuron 40:775-784.

Lau CG, Zukin RS (2007) NMDA receptor trafficking in synaptic plasticity and neuropsychiatric disorders. Nat Rev Neurosci 8:413-426.

Lee MC, Yasuda R, Ehlers MD (2010) Metaplasticity at single glutamatergic synapses. Neuron 66:859-870.

Liu L, Wong TP, Pozza MF, Lingenhoehl K, Wang Y, Sheng M, Auberson YP, Wang YT (2004) Role of NMDA receptor subtypes in governing the direction of hippocampal synaptic plasticity. Science 304:1021-1024.

Liu XY, Chu XP, Mao LM, Wang M, Lan HX, Li MH, Zhang GC, Parelkar NK, Fibuch EE, Haines M, Neve KA, Liu F, Xiong ZG, Wang JQ (2006) Modulation of D2R-NR2B interactions in response to cocaine. Neuron 52:897-909.

Ma XM, Huang J, Wang Y, Eipper BA, Mains RE (2003) Kalirin, a multifunctional Rho GEF, is necessary for maintenance of hippocampal pyramidal neuron dendrites and dendritic spines. J Neurosci 23:10593-10603.

Ma XM, Wang Y, Ferraro F, Mains RE, Eipper BA (2008a) Kalirin-7 is an essential component of both shaft and spine excitatory synapses in hippocampal interneurons. J Neurosci 28:711-724.

Ma XM, Kiraly DD, Gaier ED, Wang Y, Kim EJ, Levine ES, Eipper BA, Mains RE (2008b) Kalirin-7 is required for synaptic structure and function. J Neurosci 28:12368-12382.

Ma YY, Guo CY, Yu P, Lee DY, Han JS, Cui CL (2006) The role of NR2B containing NMDA receptor in place preference conditioned with morphine and natural reinforcers in rats. Exp Neurol 200:343-355.

Ma YY, Yu P, Guo CY, Cui CL (2011) Effects of ifenprodil on morphineinduced conditioned place preference and spatial learning and memory in rats. Neurochem Res 36:383-391.

Madara JC, Levine ES (2008) Presynaptic and postsynaptic NMDA receptors mediate distinct effects of brain-derived neurotrophic factor on synaptic transmission. J Neurophysiol 100:3175-3184.

Matsuzaki M, Honkura N, Ellis-Davies GC, Kasai H (2004) Structural basis of long-term potentiation in single dendritic spines. Nature 429:761-766.

Murakoshi H, Wang H, Yasuda R (2011) Local, persistent activation of Rho GTPases during plasticity of single dendritic spines. Nature 472:100-104.

Niethammer M, Kim E, Sheng M (1996) Interaction between the C terminus of NMDA receptor subunits and multiple members of the PSD-95 family of membrane-associated guanylate kinases. J Neurosci $16: 2157-2163$.

Pascoli V, Besnard A, Hervé D, Pagès C, Heck N, Girault JA, Caboche J, Vanhoutte P (2011) Cyclic adenosine monophosphate-independent ty- 
rosine phosphorylation of NR2B mediates cocaine-induced extracellular signal-regulated kinase activation. Biol Psychiatry 69:218-227.

Penzes P, Johnson RC, Sattler R, Zhang X, Huganir RL, Kambampati V, Mains RE, Eipper BA (2001a) The neuronal Rho-GEF Kalirin-7 interacts with PDZ domain-containing proteins and regulates dendritic morphogenesis. Neuron 29:229-242.

Penzes P, Johnson RC, Kambampati V, Mains RE, Eipper BA (2001b) Distinct roles for the two Rho GDT/GTP exchange factor domains of Kalirin in regulation of neurite outgrowth and neuronal morphology. J Neurosci 21:8426-8434.

Qian A, Buller AL, Johnson JW (2005) NR2 subunit-dependence of NMDA receptor channel block by external $\mathrm{Mg}^{2+}$. J Physiol 562:319-331.

Ratovitski EA, Alam MR, Quick RA, McMillan A, Bao C, Kozlovsky C, Hand TA, Johnson RC, Mains RE, Eipper BA, Lowenstein CJ (1999) Kalirin inhibition of inducible nitric oxide synthase. J Biol Chem 274:993-999.

Roche KW, Standley S, McCallum J, Dune Ly C, Ehlers MD, Wenthold RJ (2001) Molecular determinants of NMDA receptor internalization. Nat Neurosci 4:794-802.

Rodrigues SM, Schafe GE, LeDoux JE (2001) Intra-amygdala blockade of the NR2B subunit of the NMDA receptor disrupts the acquisition but not the expression of fear conditioning. J Neurosci 21:6889-6896.

Rosenmund C, Westbrook GL (1993) Calcium-induced actin depolymerization reduces NMDA channel activity. Neuron 10:805-814.

Rossman KL, Der CJ, Sondek J (2005) GEF means go: turning on RHO GTPases with guanine nucleotide-exchange factors. Nat Rev Mol Cell Biol 6:167-180.

Sakimura K, Kutsuwada T, Ito I, Manabe T, Takayama C, Kushiya E, Yagi T, Aizawa S, Inoue Y, Sugiyama H, Mishina M (1995) Reduced hippocampal LTP and spatial learning in mice lacking NMDA receptor epsilon 1 subunit. Nature 373:151-155.

Schiller MR, Ferraro F, Wang Y, Ma XM, McPherson CE, Sobota JA, Schiller NI, Mains RE, Eipper BA (2008) Autonomous functions for the Sec14p/ spectrin-repeat region of Kalirin. Exp Cell Res 314:2674-2691.

Schmitt JM, Guire ES, Saneyoshi T, Soderling TR (2005) Calmodulindependent kinase kinase/calmodulin kinase I activity gates extracellularregulated kinase-dependent long-term potentiation. J Neurosci 25: $1281-1290$

Schumann J, Yaka R (2009) Prolonged withdrawal from repeated noncontingent cocaine exposure increases NMDA receptor expression and ERK activity in the nucleus accumbens. J Neurosci 29:6955-6963.

Scott DB, Michailidis I, Mu Y, Logothetis D, Ehlers MD (2004) Endocytosis and degradative sorting of NMDA receptors by conserved membraneproximal signals. J Neurosci 24:7096-7109.

Sears RM, Liu RJ, Narayanan NS, Sharf R, Yeckel MF, Laubach M, Aghajanian GK, DiLeone RJ (2010) Regulation of nucleus accumbens activity by the hypothalamic neuropeptide melanin-concentrating hormone. J Neurosci 30:8263-8273.

Sheng M, Hoogenraad CC (2007) The postsynaptic architecture of excitatory synapses: a more quantitative view. Annu Rev Biochem 76:823-847.
Sobczyk A, Scheuss V, Svoboda K (2005) NMDA receptor subunitdependent $\left[\mathrm{Ca}^{2+}\right]$ signaling in individual hippocampal dendritic spines. J Neurosci 25:6037-6046.

Sotres-Bayon F, Bush DE, LeDoux JE (2007) Acquisition of fear extinction requires activation of NR2B-containing NMDA receptors in the lateral amygdala. Neuropsychopharmacology 32:1929-1940.

Tang YP, Shimizu E, Dube GR, Rampon C, Kerchner GA, Zhuo M, Liu G, Tsien JZ (1999) Genetic enhancement of learning and memory in mice. Nature 401:63-69.

Tian X, Feig LA (2006) Age-dependent participation of Ras-GRF proteins in coupling calcium-permeable AMPA glutamate receptors to Ras/Erk signaling in cortical neurons. J Biol Chem 281:7578-7582.

Tian X, Gotoh T, Tsuji K, Lo EH, Huang S, Feig LA (2004) Developmentally regulated role for Ras-GRFs in coupling NMDA glutamate receptors to Ras, Erk and CREB. EMBO J 23:1567-1575.

Tolias KF, Bikoff JB, Burette A, Paradis S, Harrar D, Tavazoie S, Weinberg RJ, Greenberg ME (2005) The Rac1-GEF Tiam1 couples the NMDA receptor to the activity-dependent development of dendritic arbors and spines. Neuron 45:525-538.

Tovar KR, Westbrook GL (1999) The incorporation of NMDA receptors with a distinct subunit composition at nascent hippocampal synapses in vitro. J Neurosci 19:4180-4188.

Wechsler A, Teichberg VI (1998) Brain spectrin binding to the NMDA receptor is regulated by phosphorylation, calcium and calmodulin. EMBO J 17:3931-3939.

Williams K (1993) Ifenprodil discriminates subtypes of the N-methyl-Daspartate receptor: selectivity and mechanisms at recombinant heteromeric receptors. Mol Pharmacol 44:851-859.

Williams MJ, Adinoff B (2008) The role of acetylcholine in cocaine addiction. Neuropsychopharmacology 33:1779-1797.

Wyszynski M, Lin J, Rao A, Nigh E, Beggs AH, Craig AM, Sheng M (1997) Competitive binding of alpha-actinin and calmodulin to the NMDA receptor. Nature 385:439-442.

Wyszynski M, Kim E, Dunah AW, Passafaro M, Valtschanoff JG, Serra-Pagès C, Streuli M, Weinberg RJ, Sheng M (2002) Interaction between GRIP and liprin-alpha/SYD2 is required for AMPA receptor targeting. Neuron 34:39-52.

Xie Z, Photowala H, Cahill ME, Srivastava DP, Woolfrey KM, Shum CY, Huganir RL, Penzes P (2008) Coordination of synaptic adhesion with dendritic spine remodeling by AF-6 and kalirin-7. J Neurosci 28:60796091.

Xin X, Ferraro F, Bäck N, Eipper BA, Mains RE (2004) Cdk5 and Trio modulate endocrine cell exocytosis. J Cell Sci 117:4739-4748.

Xin X, Wang Y, Ma XM, Rompolas P, Keutmann HT, Mains RE, Eipper BA (2008) Regulation of Kalirin by Cdk5. J Cell Sci 121:2601-2611.

Yashiro K, Philpot BD (2008) Regulation of NMDA receptor subunit expression and its implications for LTD, LTP, and metaplasticity. Neuropharmacology 55:1081-1094. 